\title{
PRELIMINARY STUDY OF URANIUM FAVORABILITY OF THE BOULDER BATHOLITH, MONTANA
}

\section{BENDIX FIELD ENGINEERING CORPORATION \\ Grand Junction Operations \\ Grand Junction, Colorado 81501}

January 1978

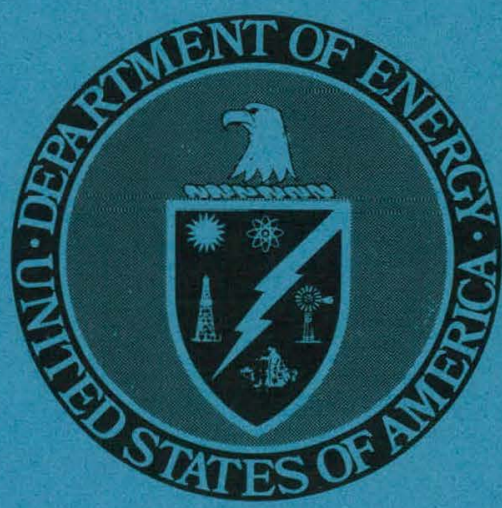

ISSUED BY THE U.S. DEPARTMENT OF ENERGY GRAND JUNCTION OFFICE UNDER CONTRACT NO. E(05-1)-1664 


\section{DISCLAIMER}

This report was prepared as an account of work sponsored by an agency of the United States Government. Neither the United States Government nor any agency Thereof, nor any of their employees, makes any warranty, express or implied, or assumes any legal liability or responsibility for the accuracy, completeness, or usefulness of any information, apparatus, product, or process disclosed, or represents that its use would not infringe privately owned rights. Reference herein to any specific commercial product, process, or service by trade name, trademark, manufacturer, or otherwise does not necessarily constitute or imply its endorsement, recommendation, or favoring by the United States Government or any agency thereof. The views and opinions of authors expressed herein do not necessarily state or reflect those of the United States Government or any agency thereof. 


\section{DISCLAIMER}

Portions of this document may be illegible in electronic image products. Images are produced from the best available original document. 
This report was prepared as an account of work sponsored by the United States Government. Neither the United States nor the United States Department of Energy, nor any of their employees, nor any of their contractors, subcontractors, or their employees, makes any warranty, expressed or implied, or assumes any legal liability or responsibility for the accuracy, completeness or usefulness of any in formation, apparatus, product or process disclosed, or represents that its use would not infringe privately owned rights.

$\cdot$ 


\section{PRELIMINARY STUDY OF URANIUM FAVORABILITY \\ OF THE BOULDER BATHOLITH, MONTANA}

S. B. Castor and J. W. Robins

\section{BENDIX FIELD ENGINEERING CORPORATION \\ Grand Junction Operations \\ Grand Junction, Colorado 81501}

This report was prepared as an account of work sponsored by the United States Govemment. Neither the United States nor the United States Department of Enezzy, nor any of their employees, nor any of their contractors, subcontractors, or their employees, makes any warranty, express or implied, or assumes any legal liability or responsibility for the accuracy, completeness or usefulness of any information, apparatus, product or process disclosed, or represents that its use would not infringe privately owned rights.

January 1978

PREPARED FOR THE U.S. ENERGY RESEARCH AND DEVELOPMENT ADMINISTRATION UNDER CONTRACT NO. E(05-1)-1664

ISSUED BY THE U.S. DEPARTMENT OF ENERGY, GRAND JUNCTION OFFICE

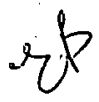


THIS PAGE

\section{WAS INTENTIONALLY LEFT BLANK}


Summary . . . . . . . . . . . . . . . . . 1

Introduction . . . . . . . . . . . . . . . . 2

Purpose .. . . . . . . . . . . . . . . . 2

Location . . . . . . . . . . . . . . . 2

Previous work . . . . . . . . . . . . . 2

Procedures . . . . . . . . . . . . . . 2

Acknowledgments . . . . . . . . . . . . . 4

Regional geology . . . . . . . . . . . . . 4

Rock units . . . . . . . . . . . . . . 4

Structure .................... 8

Uranium oc̣currences . . . . . . . . . . . . . . . 8

Chalcedony veins in batholith rocks . . . . . . 8

Chalcedony vein in Elkhorn Mountains volcanics . . . 10

Base-metal sulfide veins. . . . . . . . . . . 10

Manganese-quartz veins . . . . . . . . . . . 11

Deposits in Paleozoic rocks . . . . . . . . 1 ?

Phosphoria Formation . . . . . . . . 12

Three Forks Formation . . . . . . . . 12

Uranium in Tertiary rhyolite . . . . . . . . . 12

Favurablllly fur hew lypes of uranium depogits . . : * . 13

Midnite mine type deposits . . . . . . . . . 13 .

Porphyry uranium deposits . . . . . . . . . . 14

Uranium source rocks. . . . . . . . . . . . . . . . 14

Conclusions . . . . . . . . . . . . . . . . 15

References cited ... . ............... 17 


\section{CONTENTS (continued)}

$\underline{\text { Page }}$

Appendix A. Uranium and thorium content of samples from

the Boulder batholith project area . . . . . . . . . 21

Appendix B. Location of samples listed in Appendix A . . . . . . . . 25

Appendix C. Uranium and thorium content reported in Tilling

and Gottfried (1969) for igneous rocks from

the Boulder batholith area, and sample locations . . . . 27

\section{ILLUSTRATIONS}

Figure 1. Location map . . . . . . . . . . . . . . 3

Plate 1. Generalized geologic map of the Boulder Follows batholith ................. . page 28

2. Geologic map of Free Enterprise Mine area . . . . . Follows page 28

3. Geologic map of Clancy área ........... Follows

. $\quad$ page 28

TABLES

Table 1. Uranium and thorium contents of chalcedony vein samples . . . . . . . . . . . . . . . . 5

2. Uranium and thorium contents of samples of altered wall rock associated with chalcedony veins . . . . . . 6

3. Uranium and thorium contents of igneous rocks in the Boulder batholith project area . . . . . . . . . . . 7 


\section{SUMMARY}

The Boulder batholith of southwestern Montana is a composite Late Cretaceous intrusive mass, mostly composed of quartz monzonite and granodiorite. This study was not restricted to the plutonic rocks; it also includes younger rocks that overlie the batholith, and older rocks that it intrudes.

The Boulder batholith area has good overall potential for economic uranium deposits, because its geology is similar to that of areas that contain economic deposits elsewhere in the world, and because at least 35 uranium occurrences of several different types are present.

Potential is greatest for the occurrence of small uranium deposits in chalcedony veins and base-metal sulfide veins. Three areas may be favorable for large, low-grade deposits consisting of a number of closely spaced chalcedony veins and enriched wall rock; the Mooney claims, the Boulder area, and the Clancy area. In addition, there is a good possiblity of by-product uranium production from phosphatic black shales in the project area. The potential for uranium deposits in breccia masses that cut prebatholith rocks, in manganese-quartz veins near Butte, and in a shear zone that cuts Tertiary rhyolite near Helena cannot be determined on the basis of available information. Low-grade, disseminated, primary uranium concentrations similar to porphyry deposits proposed by Armstrong (1974) may exist in the Boulder batholith, but the primary uranium content of most batholith rocks is low.

The geologic environment adjacent to: the Boulder batholith is similar in places to that at the Midnite mine in Washington. Some igneous rocks in the project area contain more than $10 \mathrm{ppm} \mathrm{U}_{3} \mathrm{O}_{8}$, and some metasedimentary rocks near the batholith contain reductants such as sulfides and carbonaceous material. 
INTRODUCTION

PURPOSE

The project was undertaken by the Bendix Field Engineering Corporation (BFEC) for the Grand Junction Office of the U.S. Energy Research and Development Administration (ERDA).

\section{LOCATION}

The Boulder batholith is exposed over about 1,500 sq $\mathrm{mi}$ in southwestern Montana. The project area (Fig. 1) covers approximately 3,000 sq $\mathrm{mi}$, and is largely defined by the limits of the batholith, but younger overlying rocks and older host rocks are also included.

\section{PREVIOUS WORK}

The U.S. Geological Survey has published 11 geologic maps that cover 60 percent of the project area. Most of the remaining 40 percent is covered by open-file or unreleased geologic maps, and by maps included in two unpublished doctoral dissertations. References to these are listed on Plate 1. About 5 percent of the area is not covered by detailed geologic mapping.

Publications specifically dealing with uranium in the batholith include those by Roberts and Gude (1953a, 1953b), who described the geology of uranium deposits in the Clancy and Free Enterprise areas, and by Tilling and Gottfried (1969), who reported on throium, uranium, and potassium contents of igneous rocks.

Between 1.950 and 1959, many short publications that dealt with uranium deposits in the Boulder batholith were released by the U.S. Atomic Energy Commission, including two reports on drilling projects (Jarrard and Mead, 1955; Moen, 1959). Of particular interest is a detailed mineralogical. study of selected uranium veins in the batholith (Wright and others, 1957).

\section{PROCEDURES}

The project involved review of literature on the area, field investigatiuns, laboratory analyses, and petrographic studies. Field work included examination of outcrops, mines, and prospects, and collection of 122 samples for laboratory analysis and petrographic sttudy. Two areas in the Boulder batholith that contain many uranium occurrences, north of Boulder ( $\mathrm{P} \perp$. 1) and surrounding $\mathrm{Clancy}$ ( $\mathrm{P} 1.2$ ), were studied and sampled in detail to determine if distinctive geologic features, which are not characteristic of the batholith as a whole, are present in these areas. 


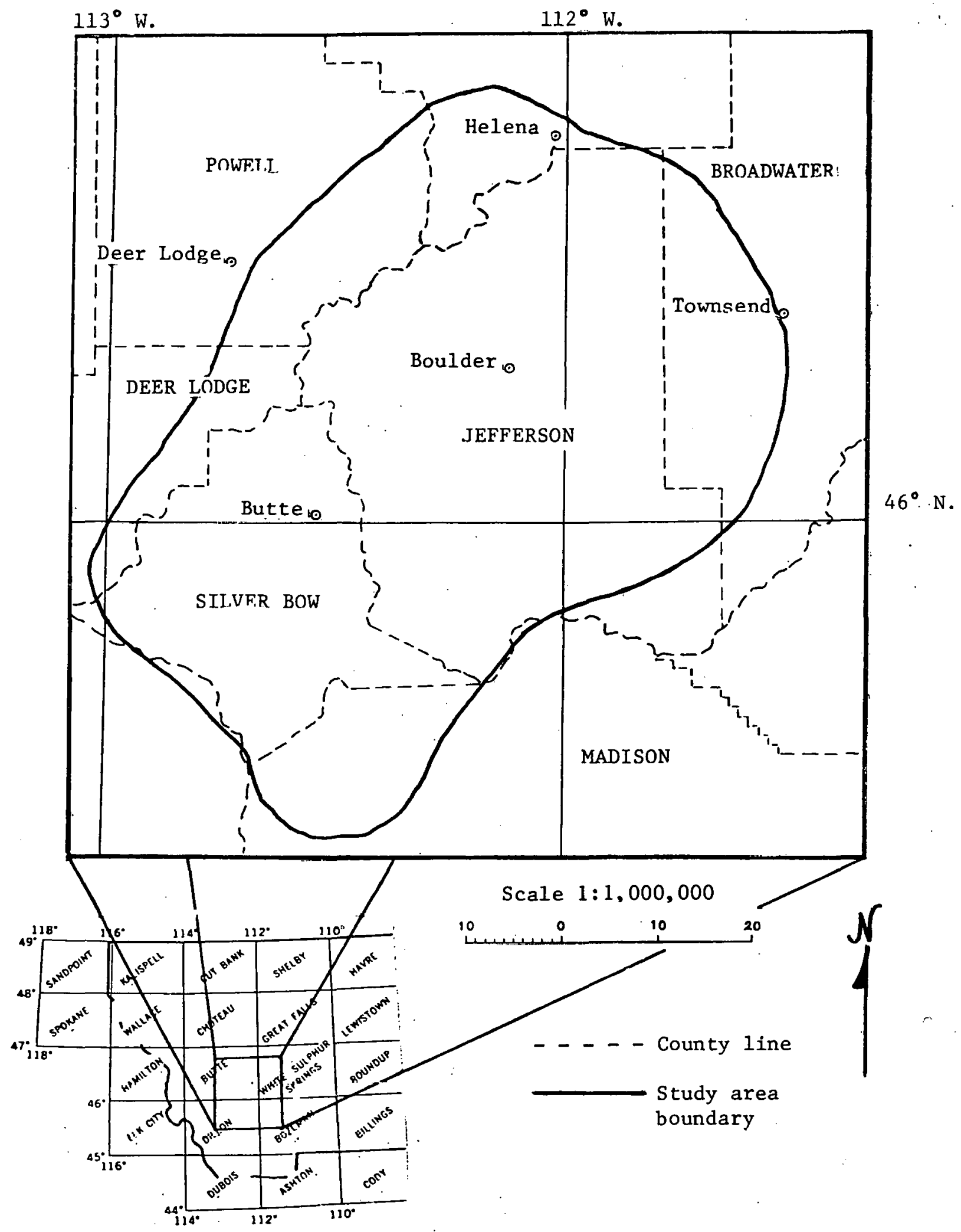

Figure 1. Location map. 
All samples were analyzed for equivalent uranium, equivalent thorium, and equivalent potassium, using gamma-spectrometric methods; and $\mathrm{U}_{3} \mathrm{O}_{8}$ contents of 61 samples were obtained by fluorometry (App. A). Petrographic analyses of 65 samples were performed to determine mineralogy and modal composition; partial modes of 40 samples were determined by stereomicroscopic examination of stained slabs (Tables 1,2,3). Uranium minerals in selected radioactive samples were identified by x-ray diffraction techniques.

\section{ACKNOWLEDGMENTS}

Robert I. Tilling of the U.S. Geological Survey, Reston, Virginia, provided information on locations of samples for which uranium, thorium, and potassium contents have been published (Tilling and Gottfried, 1969). Harry W. Smedes of the U.S. Geological Survey provided information on areas for which published or open-file geologic maps were not available.

\section{REGIONAL GEOLOGY}

\section{ROCK UNITS}

The Boulder batholith is a composite intrusion of Late Cretaceous age. It includes rocks which range in composition from gabbro to alaskite; however, at least 90 percent of the exposed rocks are quartz monzonite or granodiorite (P1. 1).

The batholith was emplaced' in sedimentary and metamorphic rocks of Precambrian to Late Cretaceous age. The Elkhorn Mountains volcanics, which include andesite, quartz latite, and rhyolite, are considered to be extrusive equivalents of the batholith, on the basis of composition and radiometric age (Robinson and others, 1968). Where contact relations have been observed, these volcanics are cut by rocks of the batholith.

Post-batholith rocks include Tertiary sedimentary rocks, which are mostly restricted to peripheral basins, and at least two volcanic units. The quartz latite Lowland Creek volcanics of early Eocene age (Smedes and Thomas, 1965) unconformably overlie the batholith on the west, and subvolcanic rocks of similar composition and age intrude the batholith. Rhyolite flows and intrusions (referred to as post-Lowland Creek rhyolite on Pl. 1), which are restricted to the northern third of the batholith, have been assigned ages that range from Oligocene to Pliocene (Becraft and others, 1963; Ruppel, 1963). 
TABLE 1. URANIUM AND THORIUM CONTENTS OF CHALCEDONY VEIN SAMPLES.

\begin{tabular}{|c|c|c|c|c|c|c|c|}
\hline $\begin{array}{l}\text { Sample } \\
\text { number }\end{array}$ & Rock type & $\begin{array}{c}\text { Fluorometric } \\
\mathrm{U}_{3} \mathrm{O}_{8} \\
(\mathrm{ppm})\end{array}$ & 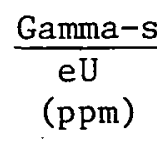 & 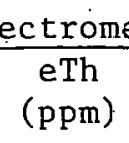 & $\frac{\text { ric data }}{\text { eU/eTh }}$ & $\begin{array}{l}\text { Uranium } \\
\text { minerals }\end{array}$ & $\begin{array}{c}\text { Plate } \\
\text { location }\end{array}$ \\
\hline 03 & $\begin{array}{l}\text { Buff to brown } \\
\text { silica breccia }\end{array}$ & 390 & 339.6 & 7.0 & 48.5 & $\begin{array}{l}\text { meta- } \\
\text { autunite }\end{array}$ & 2 \\
\hline 62 & $\begin{array}{l}\text { Buff to brown } \\
\text { silica vein }\end{array}$ & 39 & 37.3 & 8.9 & 4.2 & & 2 \\
\hline 64 & $\begin{array}{l}\text { Buff to brown } \\
\text { silica breccia }\end{array}$ & 220 & 168.7 & 18.2 & 9.3 & $\begin{array}{l}\text { fluorescent } \\
\text { opal }\end{array}$ & 2 \\
\hline 67. & $\begin{array}{l}\text { Buff to red-brown } \\
\text { silica breccia }\end{array}$ & -- & 197.2 & 6.4 & 30.8 & & 2 \\
\hline 70 & $\begin{array}{l}\text { White to buff } \\
\text { silica vein }\end{array}$ & -- & 61.4 & 14.9 & 4.1 & $\begin{array}{l}\text { fluorescent } \\
\text { opal }\end{array}$ & 3 \\
\hline 96 & $\begin{array}{l}\text { Ochre-colored } \\
\text { silica vein }\end{array}$ & -- & 38.0 & 2.0 & 19.0 & & 3 \\
\hline 97 & $\begin{array}{l}\text { Black to ochre } \\
\text { silica-barite } \\
\text { breccia }\end{array}$ & 540 & 232.3 & 34.2 & 6.8 & & 3 \\
\hline 99 & $\begin{array}{l}\text { Reddish-brown } \\
\text { silica vein }\end{array}$ & -- & 28.9 & 27.4 & 1.1 & & 3 \\
\hline 508 & Gray silica vein & 99 & 76.6 & 5.0 & 15.3 & $\begin{array}{l}\text { fluorescent } \\
\text { opal }\end{array}$ & 3 \\
\hline
\end{tabular}


TABLE 2. URANIUM AND THORIUM CONTENTS OF SAMPLES OF ALTERED WALL ROCK ASSOCIATED WITH CHALCEDONY VEINS.

\begin{tabular}{|c|c|c|c|c|c|c|c|}
\hline $\begin{array}{l}\text { Sample } \\
\text { number }\end{array}$ & Rock type & 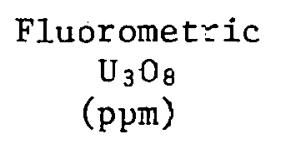 & $\frac{\mathrm{Gamma}-\mathrm{s}}{\mathrm{eU}}$ & $\begin{array}{c}\text { ectrome } \\
\text { eTh } \\
(\mathrm{ppm})\end{array}$ & $\frac{\text { ric data }}{\text { eU/eTh }}$ & $\begin{array}{l}\text { Uranium } \\
\text { minerals }\end{array}$ & $\begin{array}{c}\text { Plate } \\
\text { Jocation }\end{array}$ \\
\hline 02 & $\begin{array}{l}\text { Silicified } \\
\text { quartz monzonite }\end{array}$ & 12 & 13.8 & 19.1 & 0.7 & & 2 \\
\hline 25 & $\begin{array}{l}\text { Argillized } \\
\text { quartz monzonite }\end{array}$ & 800 & 592.6 & 21.9 & 27.1 & $\begin{array}{l}\text { meta- } \\
\text { autunite, } \\
\text { meta- } \\
\text { uranocircite }\end{array}$ & 2 \\
\hline 48 & $\begin{array}{l}\text { Argillized } \\
\text { quartz monzonite }\end{array}$ & 7 & 4.8 & 30.8 & 0.2 & & 2 \\
\hline 69 & $\begin{array}{l}\text { Argillized } \\
\text { quartz monzonite }\end{array}$ & 28 & 18.2 & 21.4 & 0.9 & & 3 \\
\hline 72 & $\begin{array}{l}\text { Chloritized } \\
\text { quartz monzonite } \\
\text { with pyrite }\end{array}$ & -- & 5.0 & 18.6 & 0.3 & & 3 \\
\hline 73 & $\begin{array}{l}\text { Silicified } \\
\text { quartz monzonite }\end{array}$ & 3910 & -- & -- & -- & coffinite & 3 \\
\hline 74 & $\begin{array}{l}\text { Silicified } \\
\text { quartz monzonite }\end{array}$ & $\therefore$ & 492.2 & 19.1 & 25.8 & $\begin{array}{l}\text { meta- } \\
\text { autunite }\end{array}$ & 3 \\
\hline 95 & $\begin{array}{l}\text { Silicified } \\
\text { alaskite }\end{array}$ & 8 & 7.2 & 30.5 & 0.2 & & 3 \\
\hline 98 & $\begin{array}{l}\text { Weakly altered } \\
\text { alaskite }\end{array}$ & -- & 25.1 & 38.2 & 0.7 & & 3 \\
\hline 511 & $\begin{array}{l}\text { Argillized } \\
\text { quartz monzonite }\end{array}$ & -- & 4.9 & 21.5 & 0.2 & & 2 \\
\hline 530 & $\begin{array}{l}\text { Argillized } \\
\text { quartz monzonite }\end{array}$ & 6 & 3.6 & 16.7 & 0.2 & & 1 \\
\hline
\end{tabular}


TABLE 3. URANIUM AND THORIUM CONTENTS OF

IGNEOUS ROCKS IN THE BOULDER BATHOLITH PROJECT AREA.

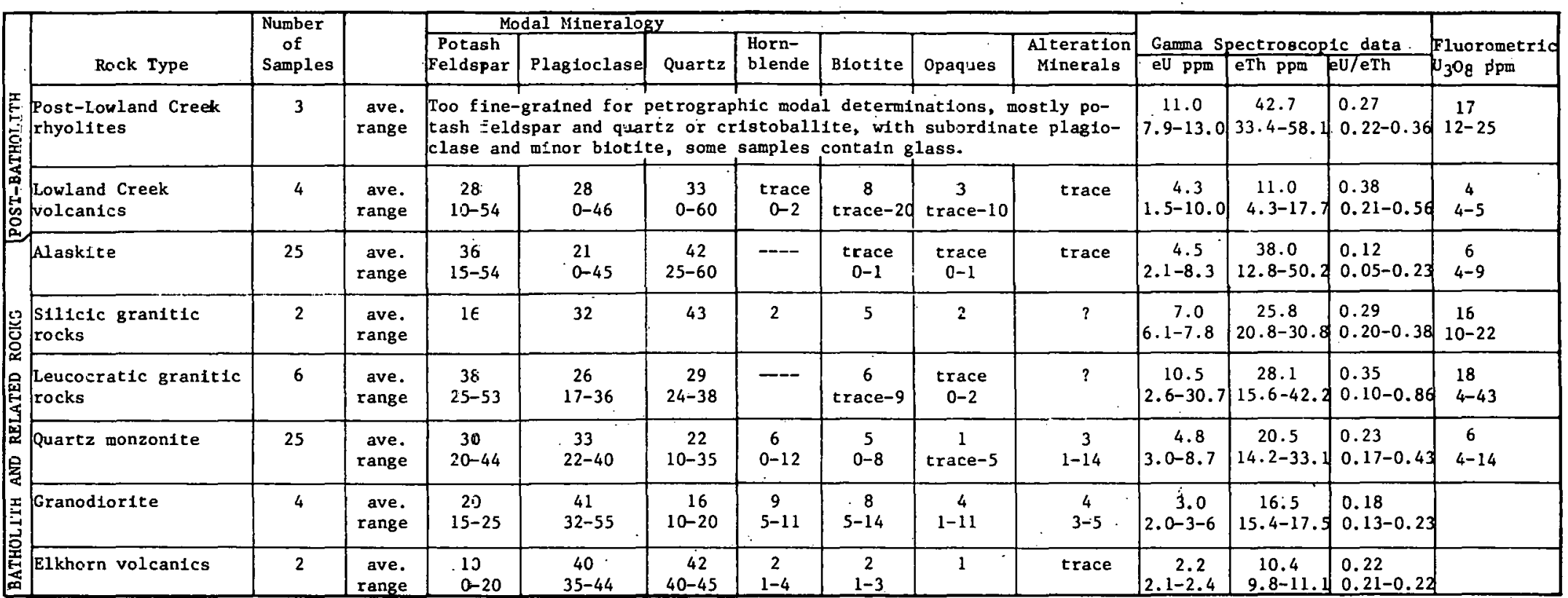




\section{STRUCTURE}

Klepper and others (1971a, p. 1578) described the batholith as a "steepsided pluton... intruded transgressively from below under a cover a few kilometers thick, and occupying a large fraction of the total thickness of the crust." However, according to Hamilton and Myers (1974, p. 365) the batholith is "a thin and shallow mass that spread over a floor of premagmatic rocks and that was covered for the most part only by its own volcanic ejecta."

A thorough review of structural features within and surrounding the batholith is beyond the scope of this report, but a few general characteristics can be cited. Prebatholith strata form a large tectonic basin, with batholithic rocks confined mostly to its center. Peripheral premagmatic rocks are younger toward the batholith, except in the Elkhorn area (about 10 mi east of Boulder, see P1. 1). The contact between the batholith and the overlying Elkhorn Mountains volcanics dips gently except along the eastern side of the batholith. Robinson and others (1968) implied that the eastern contact is fault controlled.

Faults, shear zones, dikes, and veins within the batholith generally follow three structural trends: N. $30^{\circ}$ E. parallel to the long axis of the batholith, N. $60^{\circ}$ E., and N. $85^{\circ}$ E.

\section{URANIUM OCCURRENCES}

There are 35 uranium occurrences in the project area. Most are in the northern half of the Boulder batholith. In the early 1950s, several deposits were developed, but only small amounts of ore were shipped.

Several types of uranium occurrences have been identified during this study, including one type not previously reported in the area.

\section{CHALCEDONY VEINS IN BATHOLITH ROCKS}

Approximately one third of the uranium occurrences are in single veins or in zones of discontinuous veins of chalcedony, which have been referred to in the literature as "siliceous reefs" (Wright and others, 1957). Most of the uranium produced from the Boulder batholith came from chalcedony veins: 700 tons of ore containing 0.5 percent $\mathrm{U}_{3} \mathrm{O}_{8}$ was taken from the $\mathrm{W}$. Wilson mine near Clancy (Jarrard, 1957, p. 29), and 150 tons of ore with an average grade of 0.2 percent $\mathrm{U}_{3} \mathrm{O}_{8}$ was produced from thc Free Enterprise mine near Boulder (Roberts and Gude, 1953b, p. 147).

Chalcedony veins containing uranium deposits are mostly restricted to three parts of the batholith: the Boulder area, the Clancy area, and the Mooney claims (P1. 1). All three areas are characterized by swarms of nearly vertical veins with individual strikes between N. $60^{\circ} \mathrm{E}$. and due east. Pervasive argillic alteration, chiefly affecting plagioclase and mafic minerals, accompanies the veins. Outcrops consist mostly of vein material and silicified wall rock, which forms envelopes up to $2 \mathrm{ft}$ thick adjacent to the veins. Sericitic and chloritic wall-rock alteration has been noted by Wright and others (1957), but these 
alteration types are subordinate to argillic alteration in terms of volume and intensity. Alaskite is generally only slightly altered and may crop out near veins. Outcrops of unaltered quartz monzonite or granodiorite are restricted to areas that do not contain many veins.

Uraniferous chalcedony veins are characteristically dark gray, brown, or reddish-brown; whereas barren veins are generally white, gray, or buff. Many uranium concentrations are in breccia veins which contain chalcedony and alaskite clasts in dark-gray or brown siliceous cement.

Vein mineralogy consists of microcrystalline silica with opal, white mica, limonite or hematite, minor pyrite, and local barite. Uraninite and pitchblende, in association with base-metal sulfides, are the only primary uranium minerals reported in the veins, but coffinite is present in silicified wall rock at the W. Wilson mine (sample 73, P1. 3). Many veins contain secondary uranium minerals.

The chalcedony veins are undoubtedly post batholith, but temporal relations between the chalcedony veins and Tertiary volcanic rocks are unclear. Becraft (1956, p. 273) stated that all uranium occurrences are "pre-dacite" (that is, older than the Lowland Creek volcanics), but Becraft and others (1963, p. 59) cited examples of chalcedony veins which cut dacite dikes. Wright and others (1957, p. 202) placed the age of primary uranium mineralization of the W. Wilson mine at about $45 \mathrm{~m} . \mathrm{y}$. , on the basis of two radiometric dates on uraninite.

Background radioactivity near uranium-bearing veins is slightly higher than in adjacent areas. In the vicinity of the W. Wilson mine in the Clancy area, radioactivity is several times normal background. Uranium and thorium contents for chalcedony vein samples and for altered quartz monzonite and alaskite adjacent to veins, are reported in Tables 1 and 2 . Note that the chalcedony veins, and altered rocks associated with them, have high U/Th ratios in comparison with igneous rocks in the project area (Table 3).

Because of the abundance of known uranium concentrations, potential for uranium is good in the chalcedony veins, which are similar to productive French vein deposits (Rich and others, 1975, p. 306). However, it is not likely that large single-vein deposits will be discovered because the veins are generally less than $5 \mathrm{ft}$ thick and uranium tenor is spotty along single veins or vein zones, although locally the grade exceeds $I$ percent $\mathrm{U}_{3} \mathrm{O}_{8}$ (Roberts and Gude, 1953a, p. 82 and 1953b, p. 147). Samples 3 and 64 (Table 1 and P1. 2) were collected from the same vein, but $90 \mathrm{ft}$ apart, and both are from radioactive sites extending no more than $2 \mathrm{ft}$ along the vein. Furthermore, uranium ore bodies in chalcedony veins may not have much vertical extent. In the Free Enterprise mine, economic uranium was not found at depths in excess of $80 \mathrm{ft}$ (Thurlow and Reyner, 1950, p. 11), but drill data in the vicinity of the W. Wilson mine indicate that ore grade uranium is present at a depth of about $200 \mathrm{ft}$ (Moen, 1959, p. 39). Our review of data collected on the W. Wilson vein by Wright and others (1957, p. 24 and P1. 2) and by Roberts and Gude (1953a, Pl. 19) indicates that 10,000 to 20,000 tons of ore carrying 0.2 percent $\mathrm{U}_{3} \mathrm{O}_{8}$ may have been present before high-grade ore was removed.

The potential for larger, low-grade deposits, consisting of two or more closely spaced veins and uranium-enriched wall rock, could not be determined. In some areas near the Free Enterprise mine, as many as four subparallel chalcedony veins are present over a distance of $100 \mathrm{ft}$. Samples 25 and 74 (Table 2) 
indicate that wall rock may be considerably enriched; however, both samples were taken from mine dumps, and their spatial relationship to veins is unknown.

\section{CHALCEDONY VEIN IN ELKHORN MOUNTAINS VOLCANICS}

The Redrock occurrence, about $9 \mathrm{mi}$ west of Boulder, is the only uranium deposit known in the Elkhorn Mountains volcanics. It consists of a reddishgray to brown uraniferous chalcedony vein up to $4 \mathrm{ft}$ thick. This vein is similar to chalcedony veins in the batholith rocks, except that is has vugs of drusy quartz. Irregular chalcedony veinlets are present and the wall rock is silicified and argillized adjacent to the vein.

Radioactivity of the vein exceeds 10 times background, and a sample containing 0.11 percent $\mathrm{U}_{3} \mathrm{O}_{8}$ was collected by Peterson and Hetland (1953). Locally the vein contains traces of sulfide and meta-autunite.

The host rock is a mass of breccia, approximately $500 \mathrm{ft}$ by 3,000 ft, which has been referred to as a breccia pipe (Ruppel, 1963, p. 73). Matrix material is generally lacking, and the breccia is mainly cemented by chalcedonic silica.

This type of occurrence is not promising, although uranium is associated with volcanic breccia pipes in the southwestern United States (for example, uranium accumulations are common in breccia-filled diatremes on the Navajo and Hopi Reservations; Shoemaker, 1956). Very little uranium has been produced from breccia pipes of proven volcanic origin.

\section{BASE-METAL SULFIDE VEINS}

Numerous quartz veins containing lead, zinc, and (or) copper sulfides, with associated precious metals, occur in and adjacent to the Boulder batho1ith. The productive veins in the Butte area are the best known. Uranium concentrations have been reported in at least 15 quartz vein deposits, chiefly in the northern half of the batholith, and a small amount of uranium ore was shipped from a sulfide-quartz vein in Lone Eagle mine (P1. 1).

The base-metal sulfide veins are distinguished from chalcedony veins by the presence of coarse-grained quartz gangue and considerable amounts of fineto coarse-grained base-metal sulfides. They generally occur as isolated veins or vein zones (except at Butte) and trend from N. $70^{\circ}$ E. to S. $60^{\circ} \mathrm{E}$. In the northern part of the batholith, wall-rock alteration includes sericitic, argillic, and chloritic zones proceeding outward from the veins (Becraft and others, 1963, p. 42). Similar alteration has been described in the Butte area by Guilbert and Zeihen (1964).

Becraft (1956, p. 366) considered base-metal sulfide veins in the northern part of the Boulder batholith to be older than the chalcedony veins. According to Miller (1973, Fig. F-2), the age of sulfide mineralization at Butte ranges from 56 to $63 \mathrm{m.y.,} \mathrm{based} \mathrm{on} \mathrm{K-Ar} \mathrm{dating.} \mathrm{Wright} \mathrm{and} \mathrm{others} \mathrm{(1957,} \mathrm{p.} \mathrm{203)}$ gave a maximum age of $40 \mathrm{~m} . \mathrm{y}$. (determined radiometrically) for pitchblende at the Lone Eagle mine where primary uranium mineralization is closely associated 
with late-stage microcrystalline quartz. This has led to speculation that uranium mineralization in the base-metal sulfide veins occurred synchronously with deposition in the chalcedony veins. However, a sample of sulfide-rich, coarsely crystalline, quartz vein material, without visible chalcedony or secondary uranium minerals, was collected by the authors from the Josephine mine dump; it assayed 0.30 percent $\mathrm{U}_{3} \mathrm{O}_{8}$ (sample $7, \mathrm{P} 1.1$ ).

Potential for uranium deposits is good in the base-metal sulfide veins of the Boulder batholith because of the number of occurrences and because of similar mineralogic associations elsewhere in the world. Wright and others (1957, p. 206) considered that major uranium ore bodies are more likely to be associated with base-metal sulfide veins than with chalcedony veins because the base-metal sulfide veins are larger and more persistent. The Comet and Gray Eagle mines (P1s. 1 and 2) are in a vein zone that produced about 500,000 tons of base and precious metal ore and yielded samples containing as much as 0.52 percent $\mathrm{U}_{3} \mathrm{O}_{8}$ (Becraft and others, 1963, p. 84). The main vein is 20 to $70 \mathrm{ft}$ thick, 2,000 ft long, and has been mined to a depth of $960 \mathrm{ft}$. However, anomalous radioactivity was encountered in only two of nine drill holes in the Comet-Gray Eagle vein zone, and no significant uranium concentrations were found. (Jarrard and Mead, 1955, p. 9).

\section{MANGANESE-QUARTZ VEINS}

Uranium is concentrated in a swarm of east-trending veins about 1 mi west of Butte. These veins are characterized by the association of coarsely crystalline quartz with manganese oxide and pyrite. Locally, rhodochrosite and sphalerite are present. Individual veins range from 3 to $20 \mathrm{ft}$ thick and are generally several hundred feet apart. The country rock is alaskite that has been altered to clay and (or) white mica adjacent to the veins.

Manganese-bearing veins, were considered by Guilbert and Zeihen (1964, p. 7) to be part of the outermost zone of mineralization in the Butte district. Because of its mobility, uranium in fluids which produced base and precious metal mineralization at Butte may have been driven outward into a peripheral zone.

Radioactivity up to four times background was encountered along the veins. Uranium content of three samples collected from the veins ranges from $33 \mathrm{ppm}$ to $443 \mathrm{ppm}$ (samples 537, 539, and 546, P1. 1).

The potential for economic uranium deposits in manganese-bearing veins cannot be assessed on the basis of available information, but the veins are of interest because manganese minerals are present in several productive uranium deposits elsewhere in the world. 


\section{Phosphoria Formation}

Uranium is concentrated in a 50-ft-thick phosphatic black shale in the Permian Phosphoria Formation on Humbug Mountain, about 12 mi northeast of Melrose (sample 532, P1. 1). The uranium is most abundant in layers which contain grains of a fluorescent green mineral (probably autunite or metaautunite). A sample containing $64.8 \mathrm{ppm}$ eU was coliected from this locality (sample 532, P1. 1). Swanson (1970, p. 756) estimated an average of 0:005 percent uranium for phosphate-rich rock near Melrose: Potential is good for production of by-product uranium from phosphatic rock in the area.

\section{Three Forks Formation}

Carbonaceous black shales in the Devonian Three Forks Formation, approximately $6 \mathrm{mi}$ southwest of Helena, contain anomalous amounts of uranium associated with abundant limonite and a few chalcedony veinlets: The shale contains finely divided pyrite and graphite. A sample from this locality contains

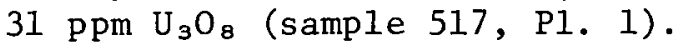

East of Melrose are several uranium occurrences in chalcedonic breccia cutting Paleozoic black shale and limestone: Radioactivity of these deposits is generally up to four times background. At one place it is nearly 10 times background and the rock contains 0.036 percent $\mathrm{U}_{3} \mathrm{O}_{8}$ (sample 533, $\mathrm{P} 1.1$ ). According to Trites and Tooker. (1953); the uranium-bearing rock fills fractures along faults and forms lenticular replacement bodies in Mississippian and Cambrian rocks, but our observations and recent detailed geological mapping (Smedes, personal commun.; 1976) indicate that the accurrences are mostly restricted to the Three Forks Formation.

The potential for uranium deposits associated with chalcedony in the Three Forks Formation is undetermined at this time. By analogy to the chalcedony veins, the potential for large deposits is poori; but geologic conditions suggest that the deposits occupy tectonic breccia bodies or solution collapse features, which may increase in size with depth. Examples of such deposits include the Orphan mine in Arizona (Gornitz and Kerr, 1970) and the Thornburg mine in Colorado (Malan and Ranspot; 1959).

\section{URANIUM IN TERTIARY RHYOLITE}

About $6 \mathrm{mi}$ southeast of Helena a small amount of rock in a shear zone cutting Tertiary rhyolite contains $220 \mathrm{ppm} \mathrm{eU}$ (sample 515, P1. 1). Except for limonite and clay, no minerals other than those found in the host rhyolite were found in the uranium-rich rock; although thin veins of white opal are nearby. A sample of the host rock, taken $50 \mathrm{ft}$ from the fault (sample 516, P1. 1) contains $25 \mathrm{ppm} \mathrm{U}_{3} \mathrm{O}_{8}$ and $13 \mathrm{ppm}$ eU. This type of uranium occurrence has not been previously reported in the project area, and potential for larger bodies of uraniferous rock cannot be demonstrated. However, significant 
uranium concentrations have been found in veins and fault zones in volcanic rocks in the Marysvale district, Utah (Gilbert, 1957), the Lakeview district, Oregon (Cohenour, 1960), and the McDermitt caldera, Nevada (Rytuba, 1976).

\section{FAVORABILITY FOR NEW TYPES OF URANIUM DEPOSITS}

Because of the large number of uranium occurrences and favorable geology, there is potential for types of uranium deposits that have not yet been discovered in the Boulder batholith area. In addition to possible uranium deposits in Tertiary sandstones peripheral to the batholith (Wopat and others, 1977), undiscovered deposits may include contact deposits in Precambrian to Mesozoic strata surrounding the batholith, and "porphyry" deposits as postulated by Armstrong (1974).

\section{MIDNITE MINE TYPE DEPOSITS}

The uranium deposit at the Midnite mine in northeastern Washington is in sulfide-rich Precambrian metasedimentary rocks adjacent to cretaceous granitic rocks that contain an average of 12 ppm U. Nash and Lehrman (1975) presented evidence that the unoxidized uranium ore is of supergene origin.

Nash (1975, p. 3) suggested that a geologic environment favorable for Midnite mine type deposits includes source rocks with more than about $10 \mathrm{ppm}$ uranium or $30 \mathrm{ppm}$ thorium, and metasedimentary host rocks with sedimentary or fracture permeability and 1 percent or more sulfides. Nash suggested that carbon compounds or ferromagnesian minerals may suffice as reductants, if sulfides are absent.

At many places bordering the Boulder batholith, conditions similar to those at the Midnite mine may exist. Shales and siltstones of Precambrian and Cambrian age near the southern end of the batholith contain abundant disseminated sulfides, and rocks of similar age and lithology border the batholith or its satellitir plutons in several other places (PI. 1). In addition, carbonaceous black shales of Paleozoic and Mesozoic age, such as those in the Three Forks Formation, are adjacent to batholith rocks.

Except for a sample of leucocratic granitic rock reported to contain 30.7 ppm Th (Tilling and Gottfried, 1969, sample 1753), adequate plutonic source rocks have not been found adjacent to prebatholith rocks. However, 26 samples of unaltered plutonir rocks from internal portions of the batholith contain adequate amounts of uranium or thorium (as defined by Nash, 1975). 'l'he postLowland Creek vnlcanic rocks are also a possible source for Midnite mine type deposits. Rhyolite adjacent to favorable host rocks near Helena contains $25 \mathrm{ppm} \mathrm{U} \mathrm{U}_{3}$ (sample 516, P1. 1). 
The Boulder batholith may contain large, low-grade accumulations of disseminated primary uranium similar to the "porphyry" deposits proposed by Armstrong (1974). Siliceous and leucocratic granites and quartz monzonites, along with alaskites that generally include some pegmatitic material, are present in many parts of the Boulder batholith (P1s. 1, 2 and 3), but the uranium content of surface samples is generally low (Table 3). Sample 84, which contains $43 \mathrm{ppm} \mathrm{U}_{3} \mathrm{O}_{8}$, is an exception. It is from a body of leucocratic granite about 4,000 ft long and 1,000 ft wide east of $\mathrm{Clancy}$ (P1. 3).

Potential for uranium deposits similar to the RUssing deposit in southwest Africa is considered to be poor in the Boulder batholith. The Rdssing deposit has been cited by some authors as a "porphyry" uranium deposit, but is now acknowledged to be of anatectic origin (Armstrong, personal commun., 1977). Although prebatholith rocks are metamorphosed adjacent to the batholith, migmatitic rocks have not been described by authors who have studied contact areas. High-grade uraniferous pegmatites similar to those which characterize the Rbssing deposit have not been found in the Boulder batholith area.

\section{URANIUM SOURCE ROCKS}

Seventy-seven samples of igneous rock were analyzed for uranium and thorium as a first step in delineating favorable uranium source rocks for supergcne depusits in or adjacent to the batholith. Mean and range values for modal mineralogy, uranium and thorium content, and uranium-thorium ratios are reported in Table 3. Analytical and location data for each sample collected are reported in Appendices A and B. Sample locations are plotted on Plates 1, 2, and 3.

Tilling and Gottfried (1969) presented thorium, uraniun, and potassium analyses for 150 samples of igneous rock from the Boulder batholith region, but did not give sample locations. Fifty-four sample locations, obtained from these authors, are reported in Appendix C (also see P1s. 1, 2, and 3).

In general, the results of the present study agree with those of Tilling and Gottfried. For instance, both studies indicate that silicic batholith rocks and post-Lowland Creek rhyolites have relatively high uranium and thorium contents. However, mean uranium contents and uranium-thorium ratios of alaskite samples collected for this study are lower than those reported by Tilling and Gottfried (1969), and the mcan uranium content of leucocratic granites and of quartz monzonites is higher.

The low uranium content of the alaskites is surprising, considering their mineralogy and high thorium content. It may be the result of primary igneous processes, such as release of uranium-enriched fluids during the last stages of crystallization, or the result of removal of uranium from the rocks subsequent to crystallization, including removal by surface weathering processes. Uranium occurrences are associated with large masses of alaskite in the Clancy and Boulder areas ( $\mathrm{P} 1$ s. 2 and 3) and west of Butte in the area that contains 
the manganese-quartz veins (P1. 1). However, large amounts of alaskite are absent near other occurrences, such as the Mooney claims (P1. 1).

The post-Lowland Creek rhyolite is considered to be a favorable uranium source rock because samples taken during this study average $17 \mathrm{ppm} \mathrm{U}_{3} \mathrm{O}_{\mathrm{a}}$ and $43 \mathrm{ppm}$ eTh. Uranium and thorium contents of rhyolite in the project area presented in Tilling and Gottfried (1969) are similarly high (samples 52C-1 and 52C-20, App. C), but six samples of post-Lowland Creek rhyolite and quartz. latite taken northwest of the project area contain only average amounts of uranium and thorium (App. C and P1. 1).

Exposures of post-Lowland Creek volcanic rock are confined to the northern part of the project area where most of the uranium occurrences are. This spatial association suggests that some of the uranium mineralization was derived from processes related to post-Lowland Creek volcanism.

Five samples of 0ligocene tuffaceous sedimentary rocks from the Helena and Townsend basins east of the batholith contain an average of $17 \mathrm{ppm}$ eU and $43 \mathrm{ppm}$ eTh (Wopat, personal commun., 1977). The exact correlation of mean uranium and thorium contents between these rocks and the post-Lowland Creek volcanic rocks indicates that they were produced during the same period of volcanism. A uranium-rich pyroclastic blanket must have once covered a larger area than that containing rhyolite exposures at this time, and many of the uranium occurrences in the Boulder batholith area may be related to Oligocene rhyolite volcanism.

\section{CONCLUSIONS}

The Boulder batholith project area is judged to be favorable for uranium resources because of the following reasons:

1. Uranium occurrences are numerous.

2. Several types of uranium occurrences are present.

3. The geologic setting is favorable for types of deposits known elsewherc, but not yet discovered in the Bnullier hathnlith area.

Potential exists for uranium deposits in chalcedony veins and base-metal sulfide veins, but it is unlikely that large single-vein deposits will be discovered. Three areas in the batholith, the Mooney claims, the Boulder area, and the Clancy area, may be favorable for large, low-grade deposits consisting of a number of closely spaced chalcedony veins and intervening wall rock Eniriched in uranium.

The potential of other types of uranium occurrences has not been determined. Uranium occurrences associated with breccia masses near Melrose are of interest because of the common association of uranium with tectonic breccias and solutioncolliapse hreccias. Too little is presently known about the uranium in manganesequartz veins near Butte and in Tertiary rhyolite near Helena to allow meaningful. speculation about favorability for deposits in these geologic environments.

The Boulder batholith area has potential for contact deposits similar to the Midnite mine in Washington. Igneous rocks in the project area contain 
anomalous amounts of uranium and thorium, and possible metasedimentary host. rocks border the batholith.

Large, low-grade "porphyry" uranium deposits might be present in the batholith because bodies of favorable types of plutonic rock are abundant; however, the uranium content of most samples of these rock types is low. 
REFERENCES CITED

Armstrong, F. C., 1974, Uranium resources of the future - "porphyry" uranium deposits, in Formation of uranium ore deposits: Internat. Atomic Energy Agency, Vienna 1974, Proc., p. 625-634.

Becraft, G. E., 1956, Uranium deposits of the northern part of the Boulder batholith, Montana: Econ. Geology, v. 51, p. 362-374.

Becraft, G. E., and Pinckney, D. M., 1961, Preliminary geologic map of the northwest quarter of the Boulder quadrangle, Montana: U.S. Geol. Survey Mineral Inv. Field Studies Map MF-183, scale 1:24,000.

Becraft, G. E., Pinckney, D. M., and Rosenblum, Samuel, 1963, Geology and mineral deposits of the Jefferson City quadrangle, Jefferson and Lewis and Clark Counties, Montana: U.S. Geol. Survey Prof. Paper 428, 101 p.

Berning, J., Cook, R., Heimstra, S. A., and Hoffman, U., 1976, The R8sising uranium deposit, Southwest Africa: Econ. Geology, v. 71, no. 1, p. $351-368$.

Cohenour, R. E., 1960, Geology and uranium occurrences near Lakeview, Oregon: Atomic Energy Comm. RME-2070, Open-File Rept., 31 p.

Doe, B. R., Tilling, R. I., Hedge, C. R., and Klepper, M. R., 1968, Lead and strontium isotope studies of the Boulder batholith, southwestern Montana: Econ. Geology, v. 63, p. 884-906.

Gilbert, R. E., 1957, Notes on the relationship of uranium mineralization and rhyolite in the Marysvale area, Utah: U.S. Atomic Energy Comm. RME-2030, Tech. Inf. Service Ext., Oak Ridge, Tenn. (Rev.) 31 p.

Gornitz, V., and Kerr, P. F., 1970, Uranium mineralization and alteration, Orphan Mine, Grand Canyon, Arizona: Econ. Geology, v. 65, no. 7, p. $751-768$.

Guilbert, J. M., and Zeihen, L. G., 1964, The mineralogy of the Butte district, Montana: Geol. Research Lab., The Anaconda Company, Butte, Montana, 21 p.

Hamilton, Warren, and Myers, W. B., 1974, Nature of the Boulder batholith: Geol. Soc. America Bull., v. 85, p. 365-378.

Jarrard, L. D., 1957, Some occurrences of uranium and thorium in Montana: Montana Bur. Mines and Geology, Misc. Contr. no. 15, 90 p.

Jarrard, L. D., and Mead, W. E., 1955, Exploration diamond drilling in the Boulder batholith, Jefferson and Silver Bow Counties, Montana: U.S. Atomic Energy Comm. RME-2031 (Pt. 1), Tech. Inf. Service Ext., Oak Ridge, Tenn., 13 p.

Klepper, M. R., Robinson, G. D., and Smedes, H. W., 1971a, On the nature of the Boulder batholith of Montana: Geol. Soc. America Bull., v. 82, p. 1563-1580. 
Klepper, M. R., Ruppel, E. T., Freeman, V. L., and Weeks, R. A., 1971b, Geology and mineral deposits, east flank of the Elkhorn Mountains Broadwater County, Montana: U.S. Geol. Survey Prof. Paper 665, 66 p.

Klepper, M. R., Weeks, R. A., and Ruppel, E. T., 1957, Geology of the southern Elkhorn Mountains, Jefferson and Broadwater Counties, Montana: U.S. Geol. Survey Prof. Paper 292, 82 p.

Knopf, Adolph, 1963, Geology of the northern part of the Boulder batholith and adjacent area, Montana: U.S. Geol. Survey Misc. Geologic Inv. Map I-381, scale 1:48,000.

Malan, R. C., and Ranspot, H. W., 1959, Geology of the uranium deposits in the Cochetopa Mining District, Saguache and Gunnison Counties, Colorado: Econ. Geology, v. 54, no. 1, p. 1-19.

Miller, R. N., 1973, Production history of the Butte district and geological functions, past and present: Guidebook for the Butte field meeting of the Society of Economic Geologists: The Anaconda Company, Butte, Montana, sec. F,

Moen, W. S., 1959, 1954 exploration drilling in the Boulder batholith, Jefferson and Silver Bow Counties, Montana: U.S. Atomic Energy Comm. RME-2044 (Rev.), Div. Raw Materials, 40 p.

Moore, G. T., 1956, The geology of the Mount Fleecer area, Montana [Ph.D. thesis]: Bloomington, Indiana Univ., $88 \mathrm{p}$.

Nash, J. T., 1975, Exploration for uranium deposits in metasedimentary rocks in the light of geologic studies of the Midnite mine: U.S. Geol. Survey Open-File Rept. 75-638, 5 p.

Nash, J. T., and Lehrman, N., 1975, Geology of the Midnite uranium mine, Stevens County, Washington -- a preliminary report: U.S. Geol. Survey OpenFilc Rept. 75-402, 36 p..

Noel, J. A., 1956, The geology of the east end of the Anaconda Range and adjacent area, Montana [Ph.D. thesis]: Bloomington, Indiana Univ., $74 \mathrm{p}$.

Peterson, W. R., and Hetland, D. L., 1953, Red Rock claim: U.S. Atomic Energy Comm. Prelim. Reconn. Rept. BB 90, Open-File Rept., 1 p.

Pinckney, D. M., and Becraft, G. E., 1961, Preliminary geologic map of the southwest quarter of the Boulder quadrangle, Montana: U.S. Geol. Survey Misc. Field Studies Map MF-187.

Prostka, H. J., 1966, Igneous geology of the Dry Mountain quadrangle, Jefferson County, Montana: U.S. Geol. Survey Bull. 1221-F, 21 p. 
Rich, R. A., Holland, H. D., and Peterson, U1rich, 1975, Vein-type uranium deposits: U.S. Energy Research and Devel. Adm. GJO-1640, Open-File Rept., 383 p.

Roberts, W. A., and Gude, A. J., 1953a, Uranium-bearing deposits west of Clancy, Jefferson County, Montana: U.S. Geol. Survey Bull. 988-F, p. 69-87.

1953b, Geology of the area adjacent to the Free Enterprise mine Jefferson County: U.S. Geol. Survey Bull. 988-G, p. 143-154.

Robinson, G. D., Klepper, M. R., and Obradovich, J. O., 1968, Overlapping plutonism, volcanism, and tectonism in the Boulder batholith region, western Montana, in Coats, R. R., and others, eds., Studies in volcanology: Geol. Soc. America Mem. 116, p. 557-576.

Ross, C. P., Andrews, D. A., and Witkind, I. J., 1955, Geologic map of Montana: Montana Bur. Mines and Geology, scale 1:500,000.

Ruppel, E. T., 1961, Reconnaissance geologic map of the Deer Lodge quadrangle, Powell, Deer Lodge, and Jefferson Counties, Montana: U.S. Geol. Survey Misc. Field Studies Map MF-174, scale 1:48,000.

1963, Geology of the Basin quadrangle, Jefferson, Lewis and Clark, and Powell Counties, Montana: U.S. Geol. Survey Bull. 1151, 121 p.

Rytuba, J. J., 1976, Geology and ore deposits of the McDermitt Caldera, Nevada-Oregon: U.S. Geol. Survey Open-File Rept. 76-535, 9 p.

Shoemaker, E. M., 1956, Occurrence of uranium in diatremes on the Navajo and Hopi Reservations, Arizona, New Mexico, and Utah, in Page, L. R. Stocking, H. E., and Smith, H. P., comps., Contributions to the geology of uranium and thorfum by the United States Geological Survey and Atomic Energy Commission for the United Natioris International Conference on Peaceful Uses of Atomic Energy, Geneva, Switzerland, 1955: U.S. Geol. Survey Prof. Paper 300, p. 179-186.

Smedes, H. W., 1966, Geology and igneous petrology of the northern E1khorn Mountains, Jefferson and Broadwater Counties, Montana: U.S. Geol. Survey Prof. Paper 510, 116 p.

1967, Preliminary geologic map of the Butte South quadrangle, Montana: U.S. Geol. Survey Open-File Map, scale 1:24,000.

1968, Preliminary geologic map of part of the Butte North quadrangle, Silver Buw, Deer Ludge, and Jefferson Counties, Montana: U.S. Geol. Survey Open-File Rept., scale 1:36,000.

Smedes, H. W., Klepper, M. R., Pinckney, D. M., Becraft, G. E., and Ruppel, E. T., 1962, Preliminary geologic map of the Elk Park quadrangle, Jefferson and Silver Bow Counties, Montana: U.S. Geol. Survey Misc. Field Studies Map MF-246, scale 1:48,000. 
Smedes, H. W., and Thomas, H. H., 1965, Reassignment of the Lowland Creek volcanics to Eocene age: Jour. Geology, v. 73, no. 3, p. 508-510.

Swanson, R. W., 1970, Minera1 resources in Permian rocks of southwest Montana: U.S. Geol. Survey Prof. Paper 313-E, p. 661-777.

Thurlow, E. E., and Reyner, M. L., 1950, Free Enterprise uranium prospect, Jefferson County, Montana: U.S. Atomic Energy Comm. RMO-678, Tech.

Inf. Service Ext., Oak Ridge, Tenn., 12 p.

Tilling, R. I., and Gottfried, David, 1969, Distribution of thorium, uranium, and potassium in igneous rocks of the Boulder batholith region, Montana, and its bearing on radiogenic heat production and heat flow: U.S. Geol. Survey Prof. Paper 614-E, 29 p.

Trites, A. F., Jr., and Tooker, E. W., 1953, Uranium and thorium deposits in east-central Idaho and southwestern Montana: U.S. Geol. Survey Prof. Paper 988-H, p. 157-208.

Von Backstrbm, J. W., 1974, Other uranium deposits, in Formation of uranium ore deposits: Internat. Atomic Energy Agency, Vienna 1974, Proc., p. 605-624.

Weeks, R. A., 1974, Geologic map of the Bull Mountain area, Jefferson County, Montana: U.S. Geol. Survey Open-File Rept. 74-354, scale 1:48,000.

Wopat, M. A., Curry, W. E., Robins, J. W., and Marjaniemi, D. K., 1.977, Favorability for uranium in Tertiary sedimentary rocks, southwestern Montana: U.S. Dept. of Energy GJBX-56(77), Open-File Rept., 152 p.

Wright, H. D., Bieler, B. H., Emerson, D. 0., and Shulbert, W. P., 1957, Mineralogy of the uranium-bearing deposits in the Boulder batholith, Montana; Final report, July 1, 1952 - December 31, 1976: U.S. Atomic Energy Comm. NYO-2074, Penn. State Univ., 228 p. 
APPENDIX A.

URANIUM AND THORIUM CONTENT OF SAMPLES FROM THE BOULDER BATHOLITH PROJECT AREA 
APPENDIX A. URANIUM AND THORIUM CONTENT OF SAIPPLES FROM THE BOULDER BATHOLITH PROJECT AREA

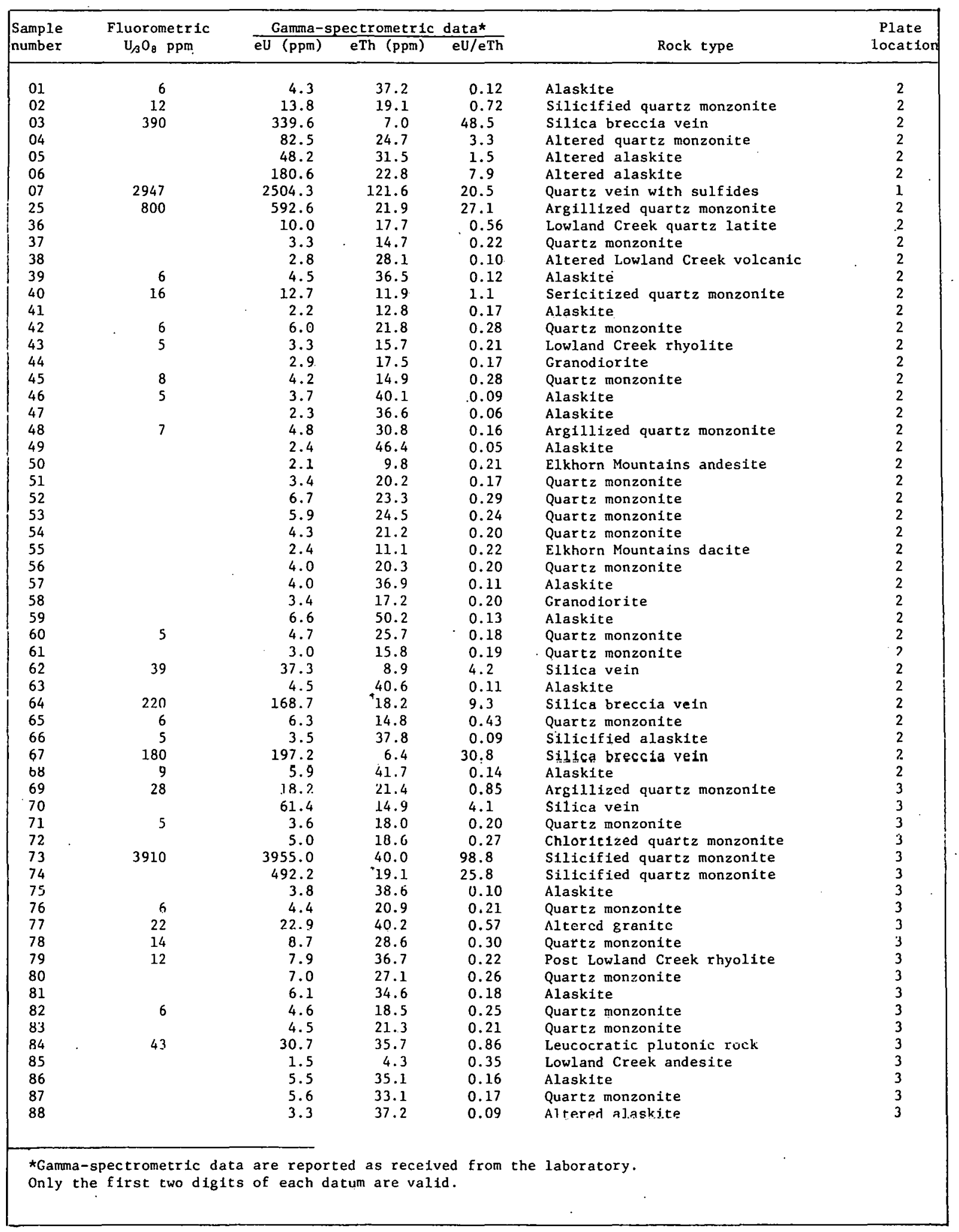




\section{APPENDI'r A. (continued)}

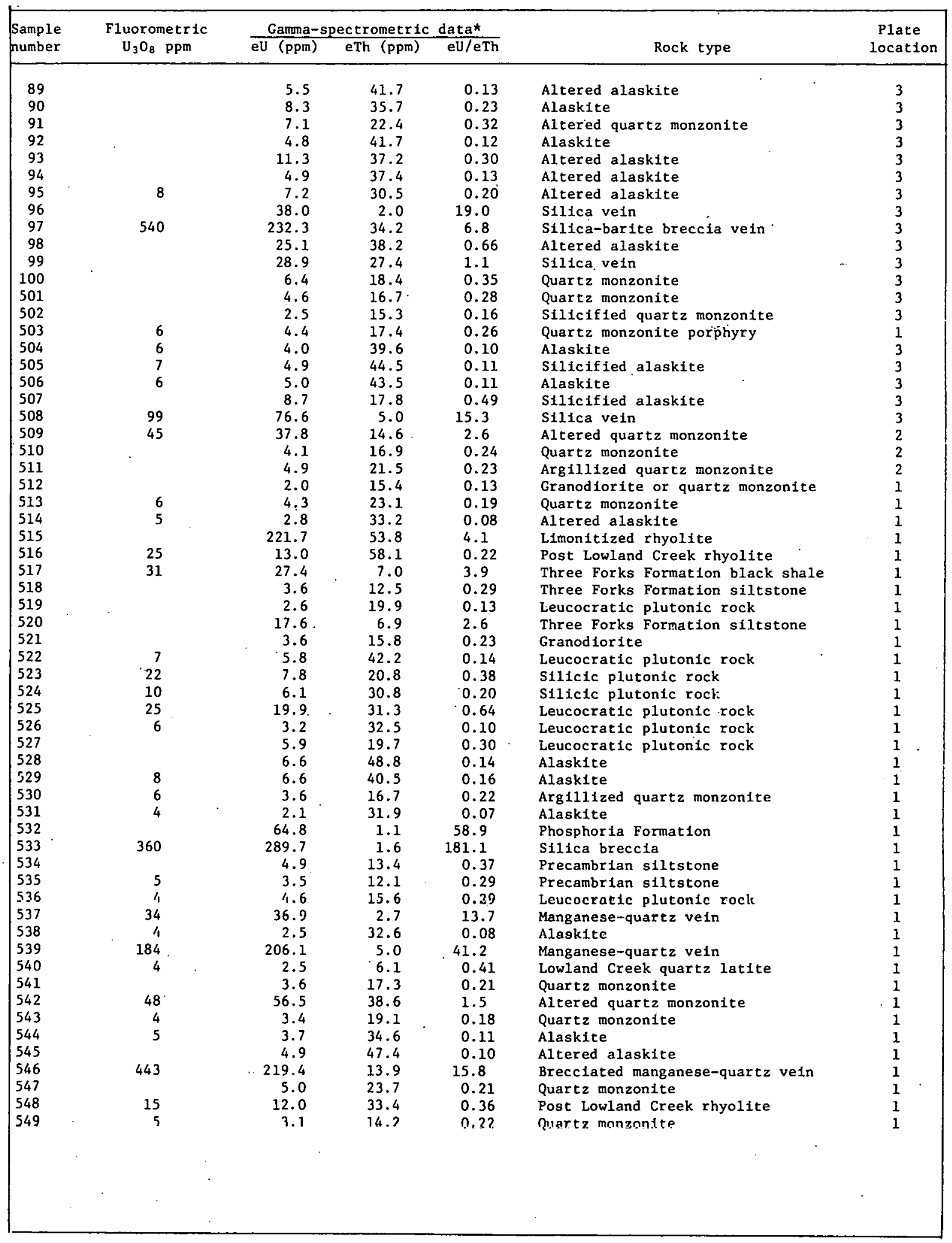


APPENDIX B.

LOCATION OF SAMPLES LISTED IN APPENDIX A 
APPENDIX B. LOCATION OF SAMPLES LISTED IN APPENDIX A

\begin{tabular}{|c|c|c|c|c|c|c|c|c|c|c|c|c|c|}
\hline $\begin{array}{l}\text { Sample } \\
\text { Number }\end{array}$ & $1 / 64$ & $1 / 16$ & $1 / 4$ & Sec. & $\mathrm{T}$ & R. & $\begin{array}{l}\text { Sample } \\
\text { Number }\end{array}$ & $1 / 64$ & $1 / 16$ & $1 / 4$ & Sec. & $\mathrm{T}$ & R. \\
\hline 01 & SW & SE & SW & 7 & $6 \mathrm{~N}$ & $4 W$ & 89 & SE & $\mathrm{NE}$ & NW & 30 & $8 \mathrm{~N}$ & $3 W$ \\
\hline 02 & SW & SE & $\mathrm{NE}$ & 19 & $6 \mathrm{~N}$ & $4 W$ & 90 & $\mathrm{NE}$ & NW & $\mathrm{NE}$ & 16 & $8 \mathrm{~N}$ & $3 W$ \\
\hline 03 & NE & $\mathrm{NE}$ & $\mathrm{SE}$ & 18 & $6 N$ & $4 W$ & 91 & $\mathrm{NE}$ & NW & $\mathrm{NE}$ & 16 & $8 N$ & $3 \mathrm{~W}$ \\
\hline 04 & SE & $\mathrm{NW}$ & $\mathrm{SE}$ & 19 & $6 \mathrm{~N}$ & $4 \mathrm{~W}$ & 92 & $\mathrm{NE}$ & $\mathrm{NW}$ & $\mathrm{NE}$ & 16 & $8 N$ & $3 \mathrm{~W}$ \\
\hline 05 & SE & $\mathrm{NW}$ & $\mathrm{SE}$ & 19 & $6 \mathrm{~N}$ & $4 \mathrm{~W}$ & 93 & $\mathrm{NE}$ & $\mathrm{NW}$ & $\mathrm{NE}$ & 16 & $8 \mathrm{~N}$ & $3 \mathrm{~W}$ \\
\hline 06 & SE & NW & SE & 19 & $6 \mathrm{~N}$ & $4 W$ & 94 & NE & NW & NE & 16 & $8 N$ & $3 \mathrm{~W}$ \\
\hline 07 & SW & SE & $\mathrm{NE}$ & 26 & $8 \mathrm{~N}$ & $6 \mathrm{~W}$ & 95 & NE & $\mathrm{NW}$ & $\mathrm{NE}$ & 16 & $8 \mathrm{~N}$ & $3 \mathrm{~W}$ \\
\hline 25 & SE & NW & $\mathrm{SE}$ & 19 & $6 N$ & $4 \mathrm{~W}$ & 96 & $\mathrm{NE}$ & $\mathrm{NW}$ & $\mathrm{NE}$ & 16 & $8 \mathrm{~N}$ & $3 W$ \\
\hline 36 & SW & NW & $\mathrm{SE}$ & 12 & $6 N$ & $5 \mathrm{~W}$ & 97 & $\mathrm{NE}$ & $\mathrm{NW}$ & NE & 16 & $8 \mathrm{~N}$ & $3 W$ \\
\hline 37 & SE & SE & NW & 12 & $6 N$ & $5 \mathrm{~W}$ & 98 & $\mathrm{NE}$ & NW & $\mathrm{NE}$ & 16 & $8 \mathrm{~N}$ & $3 \mathrm{~W}$ \\
\hline 38 & SW & SW & $\mathrm{NW}$ & 12 & $6 \mathrm{~N}$ & $5 \mathrm{~W}$ & 99 & $\mathrm{NE}$ & $\mathrm{NW}$ & $\mathrm{NE}$ & 16 & $8 \mathrm{~N}$ & $3 W$ \\
\hline 39 & SW & $\mathrm{SE}$ & NW & 12 & $6 \mathrm{~N}$ & $5 \mathrm{~W}$ & 100 & SW & $\mathrm{SE}$ & SW & 16 & $8 \mathrm{~N}$ & $3 W$ \\
\hline 40 & NW & $\mathrm{NE}$ & NW & 12 & $6 \mathrm{~N}$ & $5 \mathrm{~W}$ & 501 & SE & $\mathrm{NW}$ & NE & 8 & $8 \mathrm{~N}$ & $3 W$ \\
\hline 41 & SW & $\mathrm{NW}$ & $\mathrm{NW}$ & 7 & $6 N$ & $4 \mathrm{~W}$ & 502 & $S E$ & $\mathrm{SE}$ & $\mathrm{NW}$ & 8 & $8 \mathrm{~N}$ & $3 W$ \\
\hline 42 & SW & SW & $\mathrm{NW}$ & 7 & $6 \mathrm{~N}$ & $4 \mathrm{~W}$ & 503 & SW & SW & NW & 23 & $8 \mathrm{~N}$ & $4 W$ \\
\hline 43 & $\mathrm{SE}$ & NW & SW & 7 & $6 \mathrm{~N}$ & $4 \mathrm{~W}$ & 504 & $\mathrm{NW}$ & $\mathrm{NW}$ & $\mathrm{SE}$ & 7 & $8 N$ & $3 W$ \\
\hline 44 & SW & SE & SW & 7 & $6 \mathrm{~N}$ & $4 \mathrm{~W}$ & 505 & SW & $\mathrm{NW}$ & NE & 24 & $8 \mathrm{~N}$ & $4 \mathrm{~W}$ \\
\hline 45 & $\mathrm{NE}$ & $\mathrm{NE}$ & SW & 18 & $6 \mathrm{~N}$ & $4 \mathrm{~W}$ & 506 & SE & SW & $\mathrm{SE}$ & 13 & $8 N$ & $4 \mathrm{~W}$ \\
\hline 46 & NW & SE & SW & 18 & $6 \mathrm{~N}$ & $4 \mathrm{~W}$ & 507 & SW & $\mathrm{NE}$ & SW & 24 & $8 \mathrm{~N}$ & $4 W$ \\
\hline 47 & SE & SE & SW & 18 & $6 \mathrm{~N}$ & $4 \mathrm{~W}$ & 508 & SE & $\mathrm{NE}$ & SW & 35 & $8 \mathrm{~N}$ & $4 W$ \\
\hline 48 & $\mathrm{SE}$ & SE & $\mathrm{NW}$ & 19 & $6 \mathrm{~N}$ & $4 \mathrm{~W}$ & 509 & $\mathrm{NW}$ & $\mathrm{NE}$ & $\mathrm{NW}$ & 12 & $6 \mathrm{~N}$ & $5 \mathrm{~W}$ \\
\hline 49 & $\mathrm{NE}$ & SE & $\mathbf{N W}$ & 19 & $6 \mathrm{~N}$ & $4 \mathrm{~W}$ & 510 & $\mathrm{NW}$ & SE & NW & 19 & $6 N$ & $4 \mathrm{~W}$ \\
\hline 50 & SW & NE & SW & 35 & $7 \mathrm{~N}$ & $5 \mathrm{~W}$ & 511 & SW & $\mathrm{SE}$ & INE & 19 & $6 \mathrm{~N}$ & $4 \mathrm{~W}$ \\
\hline 51 & NW & NW & SW & 35 & $7 N$ & $5 \mathrm{~W}$ & 512 & $\mathrm{SE}$ & $\mathrm{NE}$ & NW & 29 & $9 \mathrm{~N}$ & $5 \mathrm{~W}$ \\
\hline 52 & SW & $\mathrm{NW}$ & $\mathrm{NW}$ & 2 & $6 \mathrm{~N}$ & $5 W$ & 513 & $\mathrm{NW}$ & $\mathrm{SE}$ & SW & 33 & $9 \mathrm{~N}$ & $5 W$ \\
\hline 53 & $\mathrm{NW}$ & SE & $\mathrm{NE}$ & 27 & $7 N$ & $5 \mathrm{~W}$ & 514 & $\mathrm{NE}$ & $\mathrm{SE}$ & NW & 12 & $9 \mathrm{~N}$ & SW \\
\hline 54 & SW & NW & $\mathrm{SE}$ & 34 & $7 \mathrm{~N}$ & $5 W$ & 515 & NE & $\mathrm{SE}$ & SW & 14 & $9 N$ & $3 W$ \\
\hline 55 & $\mathrm{NW}$ & NW & $\mathrm{NE}$ & 3 & $6 \mathrm{~N}$ & $5 \mathrm{~W}$ & 516 & $\mathrm{NE}$ & $\mathrm{SE}$ & SW & 14 & $9 \mathrm{~N}$ & $3 \mathrm{~W}$ \\
\hline 56 & SW & SW & SW & 27 & $7 N$ & $5 W$ & 517 & SE & $S E$ & SW & 14 & $9 \mathrm{~N}$ & $3 \mathrm{~W}$ \\
\hline 57 & $\mathrm{NE}$ & $\mathrm{NE}$ & $\mathrm{NE}$ & 33 & $7 \mathrm{~N}$ & $5 W$ & 518 & SE & $S E$ & SW & 14 & $9 N$ & $3 W$ \\
\hline 58 & $\mathrm{SE}$ & $\mathrm{SE}$ & $\mathrm{NE}$ & 33 & $7 \mathrm{~N}$ & $5 \mathrm{~W}$ & 519 & SE & SE & SW & 14 & $9 \mathrm{~N}$ & $3 \mathrm{~W}$ \\
\hline 59 & $\overrightarrow{\mathrm{NE}}$ & $\widehat{\mathrm{SE}}$ & NW & 2 & $6 \mathrm{~N}$ & $5 \mathrm{~W}$ & 520 & $\mathrm{SE}$ & $\overline{\mathrm{S}} \overline{\mathrm{E}}$ & SW & 14 & $9 \bar{N}$ & $3 W$ \\
\hline 60 & $\mathrm{NE}$ & $\mathrm{NE}$ & SW & 2 & $6 \mathrm{~N}$ & $5 \mathrm{~W}$ & 521 & $\mathrm{NW}$ & $\mathrm{NE}$ & $\mathrm{NW}$ & 26 & $9 \mathrm{~N}$ & $3 W$ \\
\hline 61 & $\mathrm{NW}$ & NW & NW & 1 & $6 \mathrm{~N}$ & $5 \mathrm{~W}$ & 522 & $\mathrm{NE}$ & $\mathrm{NE}$ & SW & 23 & $9 \mathrm{~N}$ & $3 W$ \\
\hline 62 & SW & SE & $\mathrm{NE}$ & 19 & $6 \mathrm{~N}$ & $4 \mathrm{~W}$ & 523 & NE & $\mathrm{NW}$ & $\mathrm{SE}$ & 13 & $2 \mathrm{~N}$ & $7 \mathrm{~W}$ \\
\hline 63 & $\mathrm{NE}$ & SW & SW & 17 & $6 \mathbf{N}$ & $4 W$ & 524 & $\mathrm{NE}$ & $\mathrm{NE}$ & NW & 19 & $2 \mathrm{~N}$ & $6 W$ \\
\hline 64 & NE & $\mathrm{NE}$ & $\mathrm{SE}$ & 18 & $6 \mathrm{~N}$ & $4 \mathrm{~W}$ & 525 & $\mathrm{NW}$ & $\mathrm{NE}$ & $\mathrm{SE}$ & 1 & $2 \mathrm{~N}$ & $6 \mathrm{~W}$ \\
\hline 65 & $\mathrm{NE}$ & $\mathrm{NE}$ & $\mathrm{SE}$ & 18 & $6 \mathrm{~N}$ & $4 \mathrm{~W}$ & 526 & $\mathrm{NW}$ & $\mathrm{NE}$ & $\mathrm{SE}$ & 1 & $2 \mathrm{~N}$ & $6 \mathrm{~W}$ \\
\hline 66 & SE & NW & SE & 17 & $6 \mathrm{~N}$ & $4 \mathrm{~W}$ & 527 & $\mathrm{NW}$ & $\mathrm{SE}$ & SW & 16 & $3 N$ & $5 W$ \\
\hline 67 & $S E$ & NW & $\mathrm{SE}$ & 17 & $6 \mathrm{~N}$ & $4 \mathrm{~W}$ & 528 & $\mathrm{NW}$ & $\mathrm{SE}$ & SW & 16 & $3 N$ & $5 \mathrm{~W}$ \\
\hline 68 & $\mathrm{NW}$ & SE & SE & 19 & $6 \mathrm{~N}$ & $5 \mathrm{~W}$ & 529 & $\mathrm{NW}$ & SE & NE & 20. & $3 \mathrm{~N}$ & $5 \mathrm{~W}$ \\
\hline 69 & $\mathrm{SE}$ & SE & NW & 17 & $8 \mathrm{~N}$ & $3 W$ & 530 & NE & $\mathrm{NE}$ & $\mathrm{NE}$ & 6 & $2 \mathrm{~N}$ & $9 \mathrm{~W}$ \\
\hline 70 & $\mathrm{SE}$ & SE & $\mathrm{NW}$ & 17 & $8 \mathrm{~N}$ & $3 W$ & 531 & NW & $\mathrm{NW}$ & $\mathrm{NE}$ & 28 & $3 N$ & $9 \mathrm{~W}$ \\
\hline 71 & NW & $\mathrm{NE}$ & $S E$ & 17 & $8 \mathrm{~N}$ & $3 W$ & 532 & SE & $\mathrm{SE}$ & $\mathrm{NE}$ & 32 & $1 \mathrm{~N}$ & $8 \mathrm{~W}$ \\
\hline 72 & SE & $\mathrm{NE}$ & $\mathrm{SE}$ & 17 & $8 \mathrm{~N}$ & $3 W$ & 533 & SW & $\mathrm{NE}$ & SW & 18 & $2 S$ & $8 \mathrm{~W}$ \\
\hline 73 & SE & $\mathrm{NE}$ & SE & 17 & $8 \mathrm{~N}$ & $3 \mathrm{~W}$ & 534 & $\mathrm{NW}$ & NW & $\mathrm{NE}$ & 26 & $1 \mathrm{~S}$ & $9 \mathrm{~W}$ \\
\hline 74 & NE & $\mathrm{NE}$ & $\mathrm{SE}$ & 17 & $8 \mathrm{~N}$ & $3 W$ & 535 & $\mathrm{SE}$ & NW & $\mathrm{SE}$ & 23 & $1 S$ & $9 \mathrm{~W}$ \\
\hline 75 & SW & NW & $\mathrm{NW}$ & 16 & $8 \mathrm{~N}$ & $3 \mathrm{~W}$ & 536 & NE & $\mathrm{NE}$ & $\mathrm{NE}$ & 23 & 1S & $9 \mathrm{~W}$ \\
\hline 76 & $\mathrm{NW}$ & SW & SE & 9 & $8 \mathrm{~N}$ & $3 \mathrm{~W}$ & 537 & SE & SW & $\mathrm{NE}$ & 16 & $3 N$ & $8 W$ \\
\hline 77 & NW & $\mathrm{NW}$ & $\mathrm{NW}$ & 32 & $8 \mathrm{~N}$ & $2 \mathrm{~W}$ & 538 & $\mathrm{NW}$ & SW & $\mathrm{NE}$ & 16 & $3 N$ & $8 \mathrm{~W}$ \\
\hline 78 & NW & $\mathrm{NW}$ & NW & 32 & $8 \mathrm{~N}$ & $2 \mathrm{~W}$ & 539 & NW & $\mathrm{NW}$ & NW & 15 & $3 N$ & $8 \mathrm{~W}$ \\
\hline 79 & $\mathrm{NW}$ & NW & SW & 29 & $8 \mathrm{~N}$ & $2 W$ & 540 & $\mathrm{NW}$ & $\overline{\mathrm{SE}}$ & $\mathrm{SW}$ & 10 & $3 N$ & $8 \mathrm{~W}$ \\
\hline 80 & NW & SE & SW & 30 & $8 \mathrm{~N}$ & $2 \mathrm{~W}$ & 541 & SE & NW & $\mathrm{NE}$ & 22 & $3 N$ & $8 \mathrm{~W}$ \\
\hline 81 & SW & SW & SW & 24 & $8 \mathrm{~N}$ & $2 \mathrm{~W}$ & 542 & NE & $\mathrm{NW}$ & NW & 22 & $3 \mathrm{~N}$ & $8 \mathrm{~W}$ \\
\hline 82 & SE & SE & NW & 20 & $8 \mathrm{~N}$ & $2 \mathrm{~W}$ & 543 & $\mathrm{NE}$ & $\mathrm{SE}$ & $\mathrm{SE}$ & 13 & $3 \mathrm{~N}$ & $9 \mathrm{~W}$ \\
\hline 83 & NE & SW & NW & 20 & $8 \mathrm{~N}$ & $2 W$ & 544 & $\mathrm{NW}$ & $\mathrm{NE}$ & NE & 22 & $3 N$ & $8 \mathrm{~W}$ \\
\hline 84 & $\mathrm{NW}$ & SW & $\mathrm{NE}$ & 24 & $8 \mathrm{~N}$ & $3 \mathrm{~W}$ & 545 & $\mathrm{NW}$ & $\mathrm{NE}$ & SE & 15 & $3 N$ & $8 \mathrm{~W}$ \\
\hline 85 & NW & SE & SW & 24 & $8 \mathrm{~N}$ & $3 \mathrm{~W}$ & 546 & NW & $\mathrm{NW}$ & $\mathrm{NE}$ & 23 & $3 N$ & $8 \mathrm{~W}$ \\
\hline 86 & $\mathrm{NE}$ & $\mathrm{NE}$ & SW & 15 & $8 \mathrm{~N}$ & $3 \mathrm{~W}$ & 547 & SW & NW & NW & 19 & $6 \mathrm{~N}$ & $5 W$ \\
\hline 87 & SE & $\mathrm{NE}$ & SE & 15 & $8 \mathrm{~N}$ & $3 \mathrm{~W}$ & 548 & SE & SE & $\mathrm{NW}$ & 26 & $8 \mathrm{~N}$ & $6 \mathrm{~W}$ \\
\hline 88 & NW & SW & $\mathrm{NW}$ & 15 & $8 N$ & $3 W$ & 549 & SE & NW & NE & 26 & $8 \mathrm{~N}$ & $6 \mathrm{~W}$ \\
\hline
\end{tabular}


APPENDIX C.

URANIUM AND THORIUM CONTENT REPORTED IN TILLING AND GOTTFRIED (1969) FOR IGNEOUS ROCKS FROM THE BOULDER BATHOLITH AREA, AND SAMPLE LOCATIONS 


\section{APPENDIX C. URANIUM AND THORIUM CONTENT REPORTED \\ IN TILLING AND GOTTFRIED (1969) FOR IGNEOUS ROCKS FROM \\ THE BOULDER BATHOLITH AREA, AND SAMPLE LOCATIONS.}

\begin{tabular}{|c|c|c|c|c|c|c|c|c|c|c|}
\hline $\begin{array}{l}\text { Sample } \\
\text { Number }\end{array}$ & $\begin{array}{l}\text { Uranium } \\
\text { (ppm) }\end{array}$ & $\begin{array}{c}\text { Thorium } \\
\text { (ppm) }\end{array}$ & U/Th & Rock Type & $1 / 64$ & $1 / 1 \frac{L}{6}$ & $\frac{C A}{1 / 4}$ & $\frac{O N}{\text { Sec. }}$ & $\mathrm{T}$. & R. \\
\hline 1753 & 8.0 & 30.7 & 0.26 & Leucocratic plutonic rock & NE & NE & SE & 5 & N & $8 \mathrm{~W}$ \\
\hline$\$ 1419$ & 1.7 & 5.6 & 0.30 & Mafic (syenogabbro) & NW & $\mathrm{NE}$ & NE & 21 & $9 \mathrm{~N}$ & $2 W$. \\
\hline $63 \times 350$ & & & & Mafic (syenogabbro) & $\mathrm{NE}$ & SE & NW & 9 & $2 \mathrm{~N}$ & $5 \mathrm{~W}$ \\
\hline $4 T 349$ & 1.7 & 9.3 & 0.18 & Granodiorite & $S E$ & NE & SE & 17 & $9 \mathrm{~N}$ & $3 \mathrm{~W}$ \\
\hline $2 \mathrm{~T} 1093$ & 1.7 & 8.0 & 0.21 & Granodiorite & NW & NW & SW & 14 & $1 \mathrm{~N}$ & $6 \mathrm{~W}$ \\
\hline $2 T 1065$ & 1.2 & 8.1 & 0.15 & Granodiorite & SW & SE & NE & 32 & $2 \mathrm{~N}$ & $5 \mathrm{~W}$ \\
\hline $5 T 60$ & 3.9 & 8.8 & 0.44 & Granodiorite & SE & Sw & $\mathrm{NW}$ & 21 & $1 \mathrm{~N}$ & $8 W$ \\
\hline $6 \mathrm{~K} 445$ & 20.0 & 42.0 & 0.48 & Alaskite & NW & SE & NE & 19 & $3 N$ & $5 \mathrm{~W}$ \\
\hline $62 K 00$ & 9.0 & 39.6 & 0.23 & Alaskite & $\mathrm{NW}$ & SW & NW & 3 & $4 \mathrm{~N}$ & $7 \mathrm{~W}$ \\
\hline $1 \times 241$ & 8.3 & 20.1 & 0.41 & Sillcic plutonic rock & SW & $\mathrm{NE}$ & SW & 13 & $2 \mathrm{~N}$ & $7 W$ \\
\hline 37273 & 4.6 & 18.0 & 0.26 & Quartz monzonite & $S E$ & NW & $\mathrm{NE}$ & 8 & $9 \mathrm{~N}$ & $3 W$ \\
\hline $6 \mathrm{~K} 306$ & 3.3 & 11.8 & 0.28 & Quartz monzonite & NE & NE & SW & 13 & $2 \mathrm{~N}$ & $7 \mathrm{~W}$ \\
\hline W21 & 2.1 & 12.8 & 0.16 & Leococratic plutonic rock & SW & SW & SE & 12 & $1 N$ & $7 \mathrm{~W}$ \\
\hline $2 T 275$ & 3.7 & 24.2 & 0.15 & Leucocratic plutonic rock & NW & SE & SE & 5 & 15 & $6 \mathrm{~W}$ \\
\hline $2 T 797$ & 5.0 & 17.3 & 0.29 & Leucocratic plutonic rock & SE & NE & NW & 11 & $2 S$ & $7 \mathrm{~W}$ \\
\hline $4 T 505$ & 4.4 & 17.1 & 0.26 & Post-Lowland Creek rhyolite & $\mathrm{NE}$ & SE & SW & 14 & $9 \mathrm{~N}$ & $8 \mathrm{~W}$ \\
\hline $52 \mathrm{C}-1$ & 11.6 & 44.0 & 0.26 & Post-Lowland Creek rliyolite & NE & SE & SW & 14 & $9 \mathrm{~N}$ & $3 \mathrm{~W}$ \\
\hline $52 C-8$ & 4.4 & 26.0 & 0.17 & Alaskite & SW & NW & NW & 1 & $6 \mathrm{~N}$ & $3 W$ \\
\hline $52 C-10$ & 2.9 & 13.0 & 0.22 & Quartz monzonite & $\mathrm{NE}$ & SE & SW & 23 & $9 N$ & $3 \mathrm{~W}$ \\
\hline $52 \mathrm{C}-13$ & 3.2 & 15.5 & 0.21 & Quartz monzonite & $\mathrm{NW}$ & SE & NE & 34 & $9 \mathrm{~N}$ & $3 W$ \\
\hline $52 \mathrm{C}-15$ & 4.9 & 34.0 & 0.14 & Alaskite & $\mathrm{NE}$ & SW & $\mathrm{NE}$ & 9 & $9 \mathrm{~N}$ & $3 \mathrm{~W}$ \\
\hline $52 \mathrm{C}-20 \mathrm{~b}$ & 8.5 & 34.2 & 0.25 & Post-Lowland Creek rhyolite & SW & NE & NE & 29 & $8 \mathrm{~N}$ & $3 W$ \\
\hline $52 c-20 c$ & 18.0 & 42.0 & 0.43 & Post-Lowland Creek rhyolite & SW & NE & $\mathrm{NE}$ & 29 & $8 \mathrm{~N}$ & $3 W$ \\
\hline $52 \mathrm{C}-37$ & 1.6 & 10.4 & 0.15 & Leucocratic plutonic rock & $\mathrm{NW}$ & SE & SW & 35 & $7 \mathrm{~N}$ & $4 W$ \\
\hline $52 C-45$ & 2.6 & 14.9 & 0.17 & Silicic plutonfc rock & $\mathrm{NW}$ & $\mathrm{NE}$ & $\mathrm{NE}$ & 31 & $6 \mathrm{~N}$ & $4 \mathrm{~W}$ \\
\hline $52 \mathrm{C}-52$ & 7.1 & 19.0 & 0.37 & Quartz monzonite & SW & NW & NW & 19 & $6 \mathrm{~N}$ & $5 \mathrm{~W}$ \\
\hline $52 C-60$ & 5.1 & 18.8 & 0.27 & Quartz monzonite & NE & NW & NW & 15 & $5 \mathrm{~N}$ & $6 \mathrm{~W}$ \\
\hline $52 C-65$ & 2.4 & 15.2 & 0.16 & Quartz monzonite & SW & NW & SW & 12 & $6 \mathrm{~N}$ & $7 \mathrm{~W}$ \\
\hline $52 C-79$ & 2.6 & 10.4 & 0.25 & Post-Lowland Creek qLz. latite & $\mathrm{NW}$ & SW & $S E$ & 33 & $10 \mathrm{~N}$ & $7 \mathrm{~W}$ \\
\hline $52 C-80$ & 2.6 & 18.8 & 0.14 & Post-Lowland Creek rhyolite & NE & SE & NE & 27 & $10 \mathrm{~W}$ & $8 \mathrm{~W}$ \\
\hline $52 C-81$ & 2.4 & 8.8 & 0.27 & Post-Lowland Creek qtz. latite & SE & NW & NW & 29 & $10 \mathrm{~N}$ & $8 W$ \\
\hline $52 C-83 a$ & 2.2 & 3.2 & 0.69 & Post-Lowland Creek qtz. latite & NW & NE & SW & 30 & $10 \mathrm{~N}$ & $8 W$ \\
\hline $52 C-83 b$ & 2.1 & 9.6 & 0.22 & Post-Lowland Creek qtz. latite & NW & NE & SW & 30 & $10 \mathrm{~N}$ & $8 \mathrm{~W}$ \\
\hline $52 C-113$ & $12: 1$ & 18.3 & 0.66 & Silicic plutonic rock & $\mathrm{SE}$ & SW & NW & 23 & $8 \mathrm{~N}$ & $4 W$ \\
\hline $52 \mathrm{C}-114$ & 1.6 & 17.9 & 0.09 & Quastz monzonite & NF. & $\mathrm{SW}$ & NW & $2 n$ & R: & $5 W$ \\
\hline $52 C-116$ & 2.3 & 11.1 & 0.21 & Granodiorite & NE & SW & SW & 36 & $10 \mathrm{~N}$ & $6 \mathrm{~W}$ \\
\hline $530-135^{\circ}$ & 6.2 & 31.3 & 0.20 & Post-Lowland Creek, rhyolite & SW & NW & SW & 33 & $10 \mathrm{~N}$ & $7 W$ \\
\hline $53 C-140$ & 5.7 & 16.9 & 0.34 & Granodiorite & $\mathrm{NE}$ & NE & NW & 29 & $9 \mathrm{~N}$ & $5 \mathrm{~W}$ \\
\hline $53 c-149$ & 4.5 & 16.9 & 0.27 & Quartz monzonite & NW & NW & NW & 27 & $2 \mathrm{~N}$ & $7 \mathrm{~W}$ \\
\hline $53 \mathrm{C}-150$ & 3.6 & 15.6 & 0.23 & Quartz monzonite & SW & NE & NE & 3 & $1 \mathrm{~N}$ & $7 W$ \\
\hline $53 C-154$ & 2.3 & 12.7 & 0.18 & Leucocratic plutonic rock & SE & NE & SE & 11 & $1 \mathrm{~N}$ & $7 \mathrm{~W}$ \\
\hline $53 c-163$ & 1.2 & 5.4 & 0.22 & Granodiorite & SW & NW & SE & 16 & $1 \mathrm{~N}$ & $6 \mathrm{~W}$ \\
\hline $53 C-166$ & 1.2 & 6.6 & 0.18 & Granodiorile & NE & NW & SW & 15 & IN & $6 \mathrm{~W}$ \\
\hline $53 C-168$ & 1.6 & 6.6 & 0.24 & Granodiorite & $\mathrm{NE}$ & NE & SW & 14 & IN & $6 \mathrm{~W}$ \\
\hline $53 c-191$ & 3.3 & 9.2 & 0.36 & Granodiorite & NW & NE & SW & 21 & IN & $8 \mathrm{~W}$ \\
\hline $53 \mathrm{C}-202$ & 5.2 & 15.6 & 0.33 & Quartz monzonite & NE & NE & NE & 15 & $6 \mathrm{~N}$ & SW \\
\hline $53 C-203$ & 4.3 & 23.0 & 0.19 & Silicic plutonic rock & SW & SW & SE & 34 & $7 \mathrm{~N}$ & SW \\
\hline $53 \mathrm{C}-204$ & 2.0 & 8.1 & 0.25 & Leucocratic plutonic rock & SW & NE & $\mathrm{NE}$ & 21 & $8 \mathrm{~N}$ & $4 \mathrm{~W}$ \\
\hline $53 C-205$ & 5.1 & 16.2 & 0.31 & Quartz monzonite & SE & SE & $\mathrm{NE}$ & 33 & $7 \mathrm{~N}$ & $5 W$ \\
\hline $53 C-206$ & 3.4 & 19.0 & 0.18 & Silicic plutonic rock & NE & NW & $\mathrm{SE}$ & 33 & $7 N$ & $5 \mathrm{~W}$ \\
\hline $53 C-207$ & 2.4 & 7.6 & 0.32 & Leucocratic plutonic rock & $\mathrm{NE}$ & $\mathrm{NW}$ & $\mathrm{NE}$ & 14 & $8 \mathrm{~N}$ & $5 \mathrm{~W}$ \\
\hline $53 C-209$ & 3.8 & 16.2 & 0.23 & Quartz monzonite & NW & NW & NW & 4 & $8 N$ & $5 W$ \\
\hline $54 C \cdot 248$ & 3.2 & 7.9 & 0.41 & Quartz monzonite & NW & SE & SE & 18 & IN & IW \\
\hline $54 C-249$ & 7.5 & 40.0 & 0.19 & Alaskite & $\mathrm{NE}$ & NE & NW. & 11 & $8 \mathrm{~N}$ & $4 \mathrm{~W}$ \\
\hline
\end{tabular}




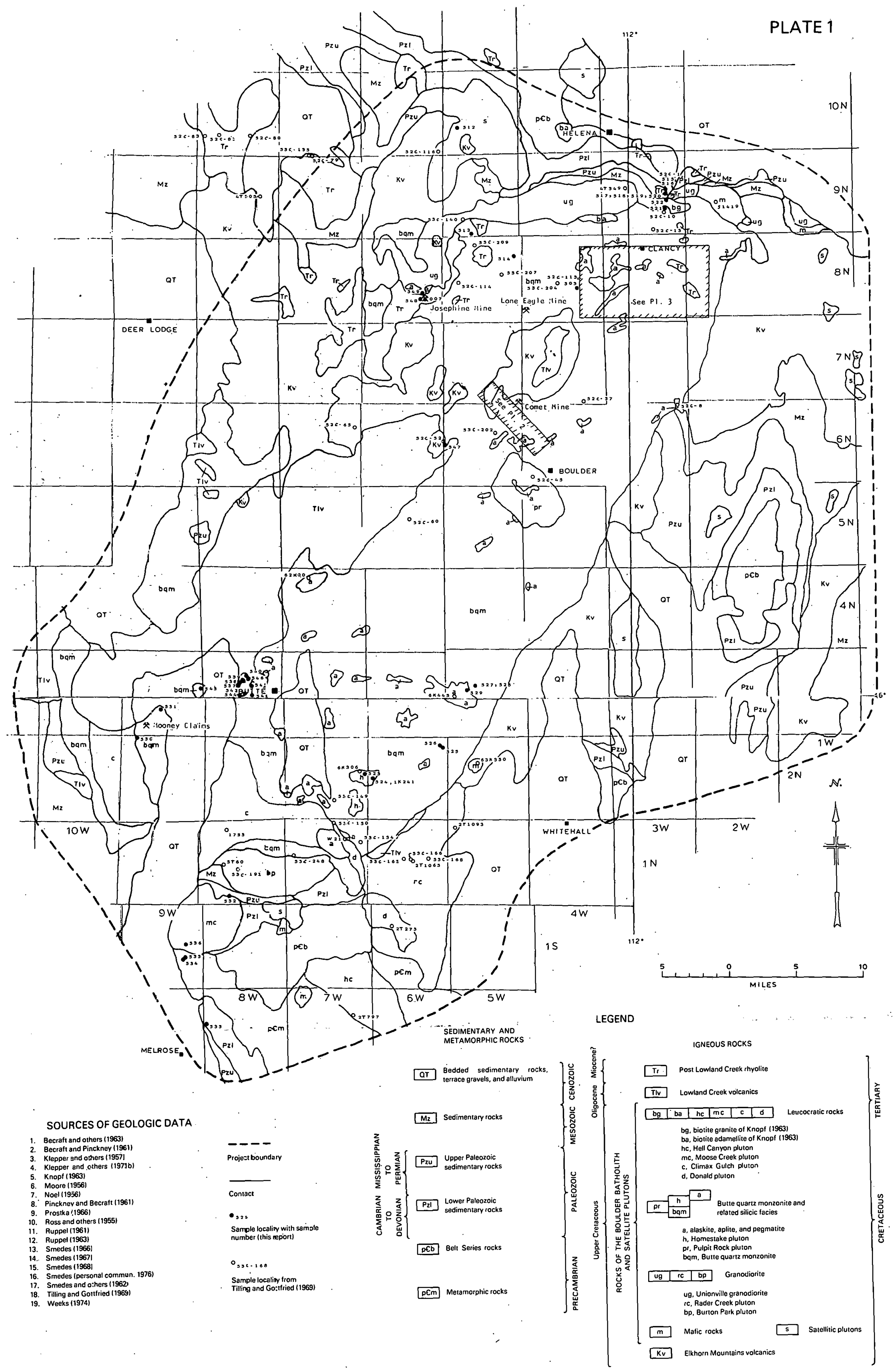

PLATE 1. GENERALIZED GEOLOGIC MAP OF THE BOULDER BATHOLITH 

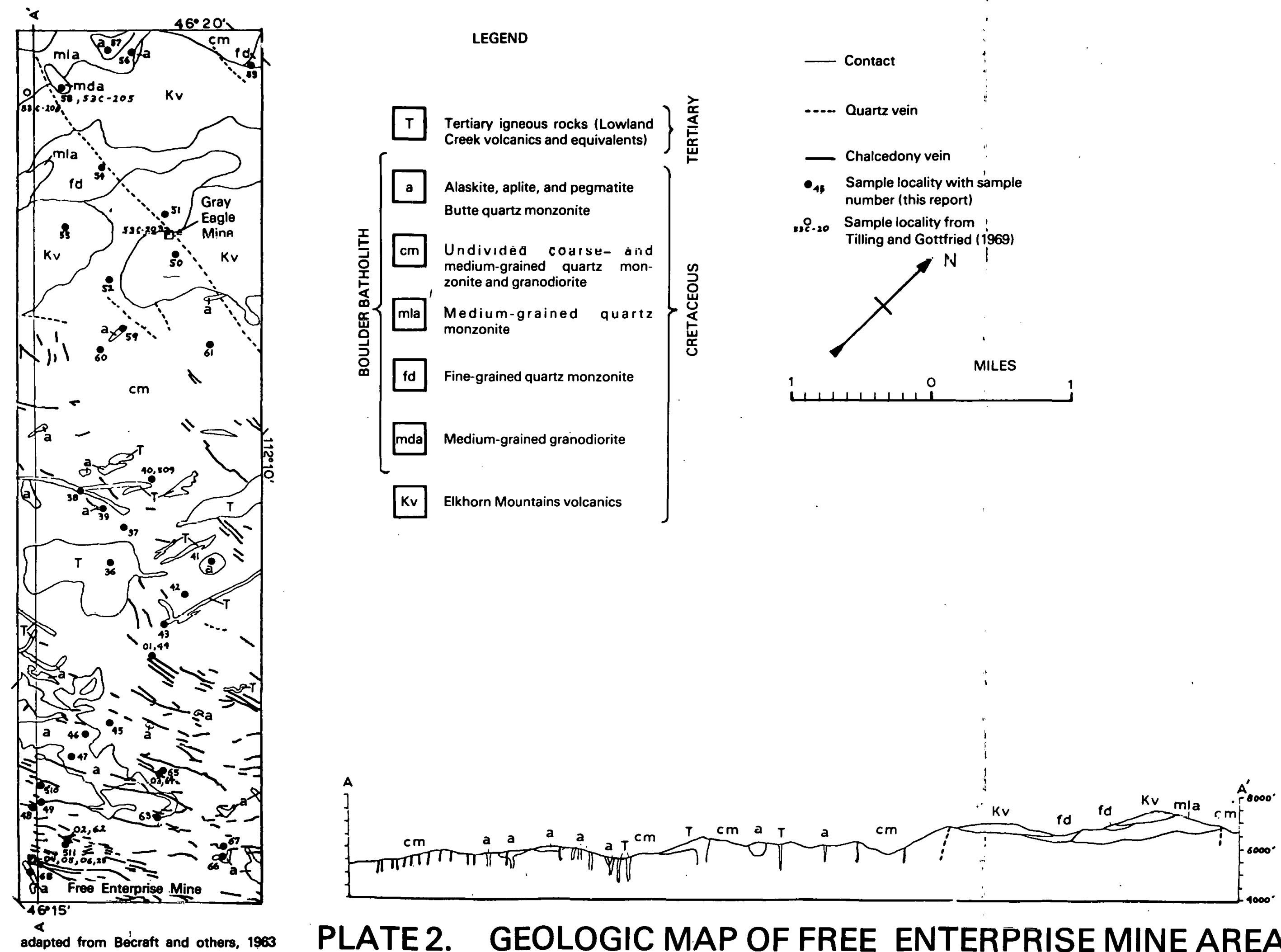

PLATE 2. GEOLOGIC MAP OF FREE ENTERPRISE MINE AREA 


\section{PLATE 3}

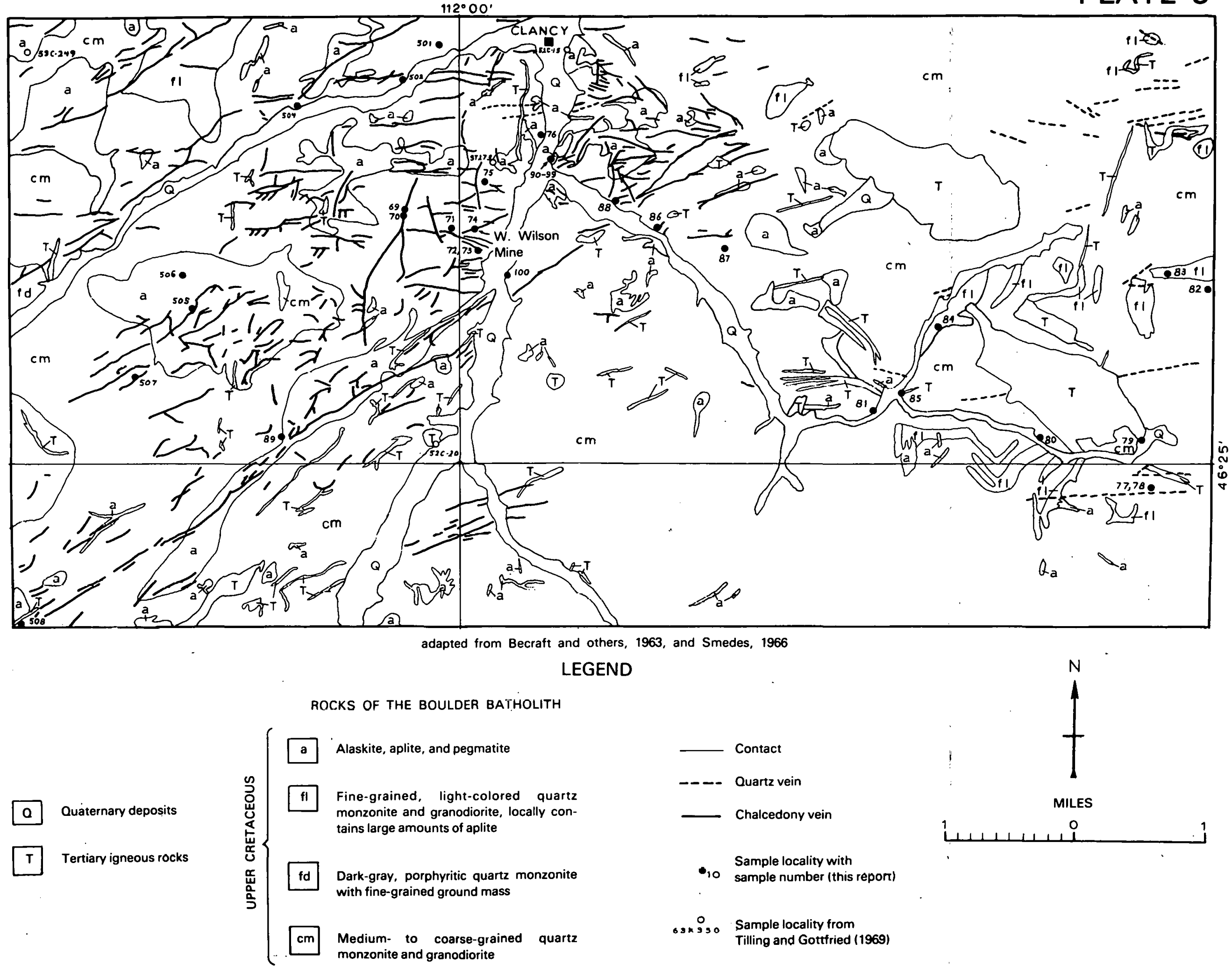

PLATE 3. GEOLOGIC MAP OF CLANCY AREA 